\title{
Masovne grobnice u hrvatskom Pounju iz Domovinskog rata - prinos viktimološkim studijama
}

\begin{abstract}
U hrvatskom je Pounju do danas otkriveno 11 masovnih grobnica, nastalih u periodu Domovinskog rata 1991. - 1993. Iz njih je ekshumirano 114 žrtava, od kojih je 99 identificirano. Većinu žrtava čine osobe posebno zaštićene međunarodnim humanitarnim pravom: civili 76,7\%, starije osobe $40,4 \%$, žene $37 \%$, ranjenici, teški bolesnici i invalidi $29 \%$. Samo su dvije osobe stradale u borbi, dok ih je 97 planski likvidirano nakon zarobljavanja. Prema etničkoj kategoriji, 93\% žrtava jesu Hrvati, 4\% Bošnjaci te 3\% Srbi. Svi su poznati egzekutori pripadnici Milicije i Teritorijalne obrane SAO Krajine. Struktura žrtava ukazuje da su masovne grobnice u hrvatskom Pounju metoda planiranog i organiziranog zločina, s ciljem etničkog čišćenja okupiranog područja, a ne posljedica borbenih djelovanja u ratu.
\end{abstract}

Jedno su od najtragičnijih obilježja Domovinskog rata u Republici Hrvatskoj masovne grobnice, koje su otkrivene na svim područjima zahvaćenima ratom. Njihova rasprostranjenost ukazuje na karakter vođenog rata, u kojem je, uz ovladavanje teritorijem, primarni cilj bilo etničko čišćenje „,nepoćudnog“ stanovništva s konačnim ciljem dobivanja etničke homogenosti teritorija na koji se aspiriralo. Pri tome se koristilo metode fizičkog uništavanja osoba, progona i prisilnog premještanja te zatočenja, uništavanja i pljačke materijalnih dobara, kulturne i vjerske baštine. ${ }^{1}$ Prema Evidenciji ekshumiranih, identificiranih i neidentificiranih posmrtnih ostataka Uprave za zatočene i nestale Ministarstva branitelja Republike Hrvatske, koja uključuje sve posmrtne ostatke osoba stradalih u vezi s oružanim sukobima, ekshumirane od 1995. (kada su počele ekshumacije na područjima oslobođenima u operacijama Bljesak i Oluja) do 21. rujna 2015., u Hrvatskoj je otkriveno ukupno 148 masovnih grobnica. Od tog su broja na području Sisačkomoslavačke županije otkrivena 43 mjesta masovnih grobnica, $\mathrm{tj}$. gotovo trećina svih masovnih grobnica. Time je, nakon hrvatskog Podunavlja s 55 grobnica, Sisačko-moslavačka županija područje na kojem je otkriveno najviše te su pronađene najveće masovne grobnice. Raspored i brojnost svih masovnih grobnica

1 GRUJIĆ I BILIĆ 2009: 29-43. 
u državi vidljiva je iz Tablice 1. Usto je u Hrvatskoj otkriveno i više od 1.400 pojedinačnih grobova.

Tablica 1.

\begin{tabular}{|c|c|}
\hline \multicolumn{2}{|c|}{ BROJ MASOVNIH GROBNICA PREMA ŽUPANIJI - EKSHUMACIJE } \\
\hline ŽUPANIJA - EKSHUMACIJE & BROJ GROBNICA \\
\hline VUKOVARSKO-SRIJEMSKA & 55 \\
\hline SISAČKO-MOSLAVAČKA & 43 \\
\hline OSJEČKO-BARANJSKA & 16 \\
\hline KARLOVAČKA & 11 \\
\hline LIČKO-SENJSKA & 8 \\
\hline POŽEŠKO-SLAVONSKA & 5 \\
\hline ŠIBENSKO-KNINSKA & 5 \\
\hline ZADARSKA & 2 \\
\hline BJELOVARSKO-BILOGORSKA & 1 \\
\hline BRODSKO-POSAVSKA & 2 \\
\hline Ukupno & 148 \\
\hline \multicolumn{2}{|c|}{$\begin{array}{c}\text { Izvor: Ministarstvo branitelja, Uprava za zatočene i nestale } \\
\text { Datum: } 21 . \text { IX. } 2015 .\end{array}$} \\
\hline
\end{tabular}

\section{Definicija i tipovi masovnih grobnica}

U Republici Hrvatskoj pojam masovne grobnice definiran je u skladu s kriterijima i standardima koje su predložili posebni izvjestitelji Ujedinjenih naroda, koji se bave izvanpravnim masovnim ili proizvoljnim egzekucijama, kao mjesto gdje su nelegalno pokopani posmrtni ostaci triju ili više žrtava, bez obilježja i mjera poštovanja prema posmrtnim ostacima. One se, s obzirom na način nastanka, mogu podijeliti na dvije osnovne skupine:

1. Grobnice nastale asanacijom terena

2. Grobnice nastale na mjestima pogubljenja ratnih zarobljenika i nasilno odvedenih civila.

1. Grobnice nastale asanacijom terena jesu one u kojima su pokopane žrtve stradale u različito vrijeme i u raznim okolnostima. Neke su osobe ubijene tijekom borbi, neke tijekom zauzimanja mjesta, a neke nakon uspostave stvarnog nadzora nad nekim područjem, pri čemu se radi o osobama koje su bile ili ratni zarobljenici ili nasilno odvedeni civili, a ubijene su na različite načine, često uz zlostavljanje i masakriranje. Njihovi su posmrtni ostaci nakon završetka borbi, tj. nakon likvidacije prikupljeni, odnosno asanirani s određenog područja i pokopani na jednome mjestu. Uobičajeno je da su u takvim grobnicama žrtve različite po statusu, spolu, širokog dobnog raspona i različitih uzroka smrti. Najveća je grobnica toga tipa u Republici Hrvatskoj Novo groblje u Vukovaru, na kojemu je ekshumirano 938 posmrtnih ostataka. 
2. Grobnice nastale na mjestima ubojstva ratnih zarobljenika i civila ili u njihovoj neposrednoj blizini homogenije su po svojem sastavu. Žrtve pronađene u njima najčešće su ubijene u istoj situaciji, sličnog su spola i statusa, približnih godina, a uzrok smrti uglavnom su strijelne ozljede. Najveća je otkrivena grobnica toga tipa masovna grobnica na Ovčari nedaleko od Vukovara, gdje su 1996. ekshumirani posmrtni ostaci 200 ubijenih, ranjenika i osoblja iz Vukovarske bolnice.

Masovne se grobnice, s obzirom na način nastanka, dijele na primarne i sekundarne. U primarnima su pokopane žrtve odmah nakon stradanja, odnosno pronalaska, dok se u sekundarnima nalaze žrtve iskopane iz primarnih grobnica i premještene na nove lokacije. U njima mogu biti žrtve iz grobnica nastalih asanacijom terena, kao i iz grobnica na mjestima pogibije. Razlog je nastanka sekundarnih grobnica prikrivanje ratnih zločina, zbog čega su se vršile ekshumacije posmrtnih ostataka te su se oni skrivali premještanjem na druga mjesta. Tako se otežavalo pronalazak, rekonstrukciju pogibije i identifikaciju žrtava te time izravno prikrivalo zločine.

Prema broju žrtava pronađenih u njima, masovne grobnice dijele se na manje (koje sadrže tri do 10 posmrtnih ostataka) i veće (s više od 10 posmrtnih ostataka). ${ }^{2}$

\section{Masovne grobnice i pojedinačni grobovi u hrvatskom Pounju}

Iako je još od kraja rujna 1990. na prostoru današnje Sisačko-moslavačke županije bilo nemira, koji su postupno prerastali u oružane aktivnosti s odlikama terorizma (miniranje javnih i privatnih objekata, zaprečavanje i uništavanje prometne infrastrukture, nasrtaji na pojedince), srpska oružana pobuna izbila je tek nakon proglašenja neovisnosti Republike Hrvatske 25. lipnja 1991. Uslijedila je oružana konfrontacija hrvatskih (policija i Zbor narodne garde (ZNG) Republike Hrvatske) sa srpskim (Milicija i Teritorijalna obrana Srpske autonomne oblasti (SAO) Krajine, JNA, četnički dobrovoljci) oružanim postrojbama uzduž hrvatskosrpske etničke razdjelnice na prostoru Banovine, od Topuskoga do Dvora. ${ }^{3}$ No, intenzitet nasilja pobunjenika nad civilnim stanovništvom i zarobljenim pripadnicima hrvatskih vojnih i policijskih postrojbi bio je takav da su ovdje nastale prve masovne grobnice u Hrvatskoj, već krajem srpnja, odnosno početkom kolovoza 1991. i to baš u hrvatskom Pounju, na prostoru koji su tada upravno obuhvaćale skupštine općina Kostajnica i Dvor, a koji obuhvaća banovinsko Pounje i Zrinsku goru, $\mathrm{tj}$. jugoistočnu Banovinu. Primarna je meta bilo hrvatsko stanovništvo, koje je u ukupnoj masi stanovnika (29.406) činilo 19\% (5.690), tj. u kostajničkoj općini $29 \%$ (4.295), a u dvorskoj 10\% (1.395) populacije. ${ }^{4}$

\footnotetext{
GRUJIĆ 2000: 29-37.

NAZOR 2007.

4 Popis stanovništva 1991. - narodnosni sastav stanovništva Hrvatske po naseljima, 1992: 88-91, 118-119.
} 


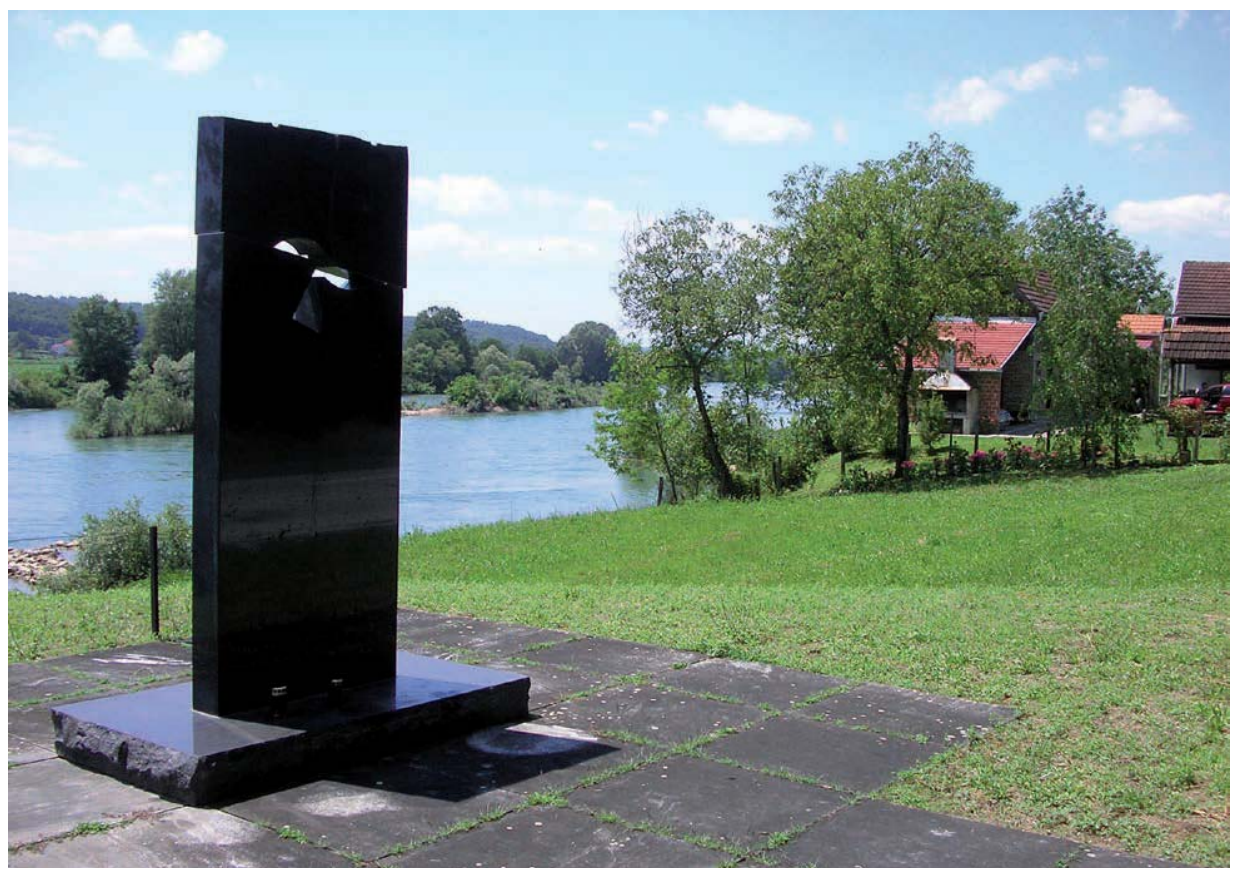

01 - Spomen obilježje mjesta masovne grobnice žrtava iz Domovinskog rata Skelište u Baćinu/Hrvatska Dubica

Do danas je u hrvatskom Pounju otkriveno 11 masovnih grobnica, koje su nastale u periodu 1991. - 1993., s ukupno 114 žrtava, od čega 15 neidentificiranih.

Prema Zakonu o obilježavanju mjesta masovnih grobnica žrtava iz Domovinskog rata, a s ciljem očuvanja uspomene na žrtve, Ministarstvo branitelja sustavno provodi proces obilježavanja mjesta masovnih grobnica postavljanjem jednakog spomen-obilježja, koje je rad akademskog kipara Slavomira Drinkovića. Dosad je u Pounju obilježeno deset mjesta. ${ }^{5}$

Policijske su istrage pokazale da su egzekutori svih žrtava u masovnim grobnicama pripadnici Milicije i Teritorijalne obrane SAO Krajine, tj. Republike Srpske Krajine (RSK). Treba navesti da u Pounju postoji još jedna, dvanaesta masovna grobnica - na pravoslavnom groblju u Dvoru. Nastala je 1995. prilikom asaniranja terena te su u njoj pokopana tijela pronađena nakon operacije „Oluja“. Pretpostavlja se da se većinom radi o tijelima pripadnika Srpske vojske Krajine i civila stradalima tijekom ove operacije. ${ }^{6}$ Prema dostupnim podacima, do sada je

5 Zakon o obilježavanju mjesta masovnih grobnica žrtava iz Domovinskog rata. K1. 564-02/9603/01., od 14. XI. 1996., u: Narodne novine (Zagreb), br. 100, 28. XII. 1996.

6 Vojna operacija ,Oluja“ i poslije: izvještaj 2001: 246. 
Jakša Raguž - Masovne grobnice u hrvatskom Pounju iz Domovinskog rata...

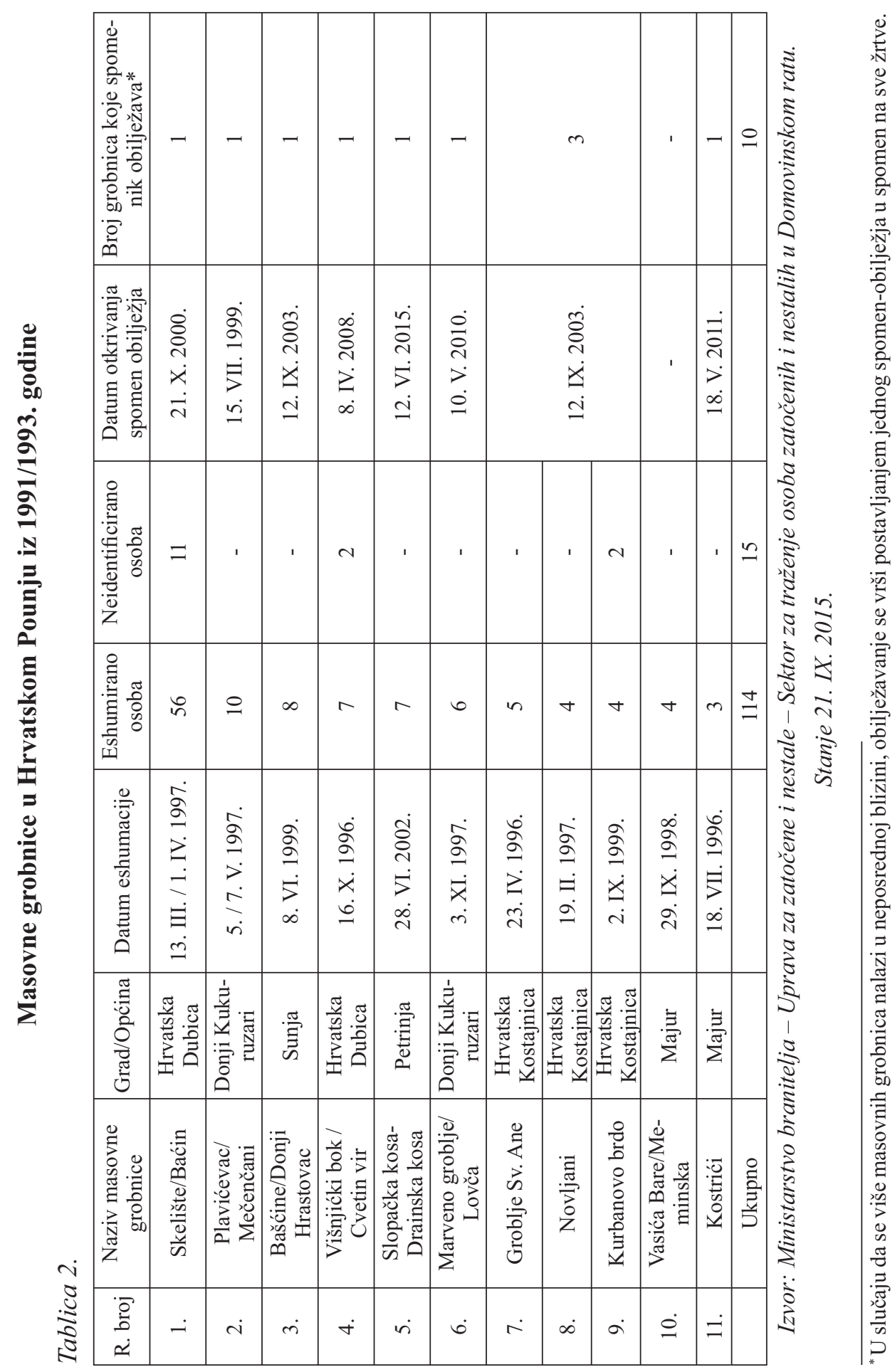


ekshumirano šezdesetak tijela, a većinom se radi o osobama srpske nacionalnosti sa šireg prostora Korduna. Nadalje, očekuje se da bi trebao biti ekshumiran još jedan manji broj tijela, a proces identifikacije dijela ekshumiranih još je u tijeku. Budući da su, dakle, postupci još u tijeku, a niti dokumentacija nije dostupna, ova grobnica nije mogla biti obrađena, pa je rad ograničen na 11 grobnica iz perioda 1991. - 1993. Prema vremenu nastanka, ovih 11 masovnih grobnica u Pounju mogu se podijeliti na tri skupine:

- nastale krajem srpnja i početkom kolovoza 1991., kao posljedica masovnih likvidacija osoba zarobljenih u srpskoj napadnoj operaciji „Žaoka“, čiji je cilj bilo osvajanje hrvatskog Pounja i grada Gline

- nastale u rujnu 1991. tijekom borbi za grad Hrvatsku Kostajnicu i neposredno nakon njegova pada, kada dolazi do masovne likvidacije zarobljenih policajaca, gardista i civila

- nastale tijekom srpske okupacije hrvatskog Pounja, počevši od kraja rujna 1991., pa do siječnja 1993. One su rezultat etničkog čišćenja nesrpskog stanovništva, koje nije izbjeglo tijekom ljeta 1991., te likvidacije pripadnika Hrvatske vojske i Armije Bosne i Hercegovine, zarobljenih u sukobu sa srpskim snagama.

Prema načinu nastanka, 10 masovnih grobnica nastalo je na mjestima pogubljenja ratnih zarobljenika i civila, a jedna je na kostajničkom gradskom groblju, uvjetno rečeno, nastala asanacijom terena. Sve su primarne, tj. u njima su pokopane žrtve neposredno nakon stradanja, odnosno pronalaska. Glede zajedničkih terenskih obilježja lokacija grobnica u Pounju, pet ih je smješteno uz rubove šuma, odnosno šumske putove, dvije u močvarnom terenu, a četiri na rubovima naselja. Ni kod jedne se pri pokopu tijela nisu poštovale Ženevske konvencije. ${ }^{7}$ Leševi su nabacani jedan preko drugog, pri zakapanju tijela su se oštećivala, a uz cjelovite posmrtne ostatke nađeni su brojni amputirani i smrskani dijelovi tijela.

Tek nakon oslobađanja okupiranih područja bilo je moguće početi s ekshumacijama masovnih grobnica, s ciljem utvrđivanja sudbine nasilno odvedenih i nestalih osoba, te pronalaska tijela poginulih osoba. Inače, prva lociranja masovnih grobnica te ekshumacije i identifikacije posmrtnih ostataka izvršena su još 1992. na prostoru zapadne Slavonije, oslobođenom krajem 1991. Na Banovini se s potragom za grobnicama počelo u rujnu 1995., kada je i izvršena prva ekshumacija (Vila Gavrilović u Petrinji). Same ekshumacije tijela bile su završni dio planskog interresornog traganja više državnih tijela Republike Hrvatske za

Prema standardima propisanima Ženevskom konvencijom za zaštitu žrtava rata, tijela treba pokopati jedno do drugog, s razmakom među njima. Grobnice nastale na ovaj način jesu, primjerice, one u Kninu, Gračacu i Petrinji, kada su nakon operacije „Oluja“ 1995. asanirana područja na kojima su se odvijale borbe. 
posmrtnim ostacima poginulih, nasilno odvedenih i nestalih hrvatskih državljana. Radne skupine koje su ih vršile u tom su sustavu bile neposredna izvršna tijela. ${ }^{8}$

Osim masovnih, u Pounju je nađen veliki broj pojedinačnih grobova, u kojima su bili pokopani ostaci najviše dvojice poginulih hrvatskih policajaca i gardista, kao i onih koji su ubijeni nakon zarobljavanja te poginulih ili nasilno odvedenih civila. Osim na nenaseljenim područjima, ovi su se grobovi otkrivali u dvorištima te ruševinama kuća i crkava. Kod pojedinačnih grobova treba naglasiti da je u većem broju mjesta pronađeno više tih grobova s posmrtnim ostacima osoba pogubljenih, istodobno ili u bliskom razdoblju, od strane istih počinitelja ili od počinitelja istog statusa. Iako ti grobovi pravno nemaju status masovnih grobnica (već bi ih se uvjetno moglo nazvati skupovima grobova), budući da se radi o velikom broju posmrtnih ostataka na malom prostoru, za neka se naselja može govoriti o čitavom mjestu kao o masovnoj grobnici (odnosno o skupu grobova). Takva su naselja Hrvatska Kostajnica (groblje sv. Roka, brdo Djed, ruševine crkve sv. Nikole), Hrvatska Dubica, sela Kostrići, Struga, Cerovljani, Volinja, Zrin... No, to nije tema ovoga rada. Glede 11 masovnih grobnica, one su predstavljene kronološki, redoslijedom nastanka, tj. masovnih likvidacija žrtava.

\section{Marveno groblje/Lovča}

Smješteno na istočnim obroncima Zrinske gore, Marveno groblje na lokaciji Berek, između sela Lovča i Borojevići, prije Domovinskog rata koristilo se kao odlagalište uginulih životinja. Krajem srpnja 1991., tijekom srpske operacije „Žaoka“, služilo je kao stratište zarobljenog pripadnika ZNG-a i nasilno odvedenih civila hrvatske nacionalnosti, pa je nastala masovna grobnica. Nakon oslobođenja Policijska uprava (PU) sisačko-moslavačka operativnim radom doznala je da bi ondje trebala biti tijela desetak Hrvata. U pitanju je bilo veliko područje, na kojem je bilo teško utvrditi točnu lokaciju grobnice. Iz tog razloga Komisija za zatočene i nestale Vlade Republike Hrvatske tri je puta: od 24. do 27. rujna 1996., 17. listopada 1996. te 1. srpnja 1997. provela neuspješna iskapanja ${ }^{9}$, prije no što se utvrdila točna lokacija. Tek su probna iskapanja u listopadu 1997. potvrdila pronalazak masovne grobnice. Nakon toga, 3. studenog 1997.

GRUJIĆ I BILIĆ 2009: 33; PLESKALT 2009: 44-101.

9 Ministarstvo branitelja - Uprava za zatočene i nestale - Sektor za traženje osoba zatočenih i nestalih u Domovinskom ratu (dalje: MB-UZN-STOZNDR). Dopis Komisije za zatočene i nestale Vlade RH. Ur. br. 50412-96-3133-01., od 20. IX. 1996.; Zapisnik Istražnog odjela Županijskog suda Sisak od 17. X. 1996. u predmetu provođenja istražnih radnji ekshumacija posmrtnih ostataka civilnih i vojnih žrtava rata na području općine H. Kostajnica; Zapisnik Istražnog odjela Županijskog suda Sisak od 1. VII. 1997. u predmetu provođenja istražnih radnji ekshumacija posmrtnih ostataka civilnih i vojnih žrtava rata na području općine H. Kostajnica. 
na toj je lokaciji ekshumaciju izvršila 13-člana mješovita Radna grupa. ${ }^{10} \mathrm{Na}$ dubini od 1,5 metara, na prostoru veličine 200 x 150 metara, nađena su tijela šestorice mlađih muškaraca u ostacima civilne odjeće. Kod pet ekshumiranih osoba otkriveno je da su im ruke vezane žicom ili konopcem, a oko glave na području očiju nađene su kružno prilijepljene ljepljive trake ili vezane marame. Dakle, prilikom likvidacije bile su vezanih ruku i očiju. Tijela su dobila identifikacijske oznake u rasponu od NN 387 do NN 392 te su otpremljena u Zavod za sudsku medicinu i kriminalistiku u Zagreb radi obavljanja obdukcije i otkrivanja identiteta. ${ }^{11}$ Obdukcijama je utvrđeno da su sve žrtve stradale od strijelnih ozljeda iz vatrenog oružja te da je većina ubijena ispaljivanjem rafala ili pojedinačnog metka izravno u glavu. ${ }^{12}$

Uslijedio je višegodišnji proces identifikacije, koji do danas nije službeno okončan. Glede identiteta i statusa žrtava, on je sljedeći:

- tijelo NN 387, koje se razlikovalo od ostalih iz grobnice jer nije bilo vezano, 2009. u navedenom je Zavodu metodom analize DNK identificirano kao Srećko Kitonić (1964.), inženjer šumarstva iz Hrvatske Dubice. Bio je tajnik Hrvatske demokratske zajednice Hrvatske Dubice i pripadnik dubičkog pričuvnoga ZNG-a. Pobunjeni su ga Srbi ranili i zarobili u zasjedi kod Šupljeg kamena (kod Hrvatske Kostajnice) 26. srpnja $1991 .{ }^{13}$

- tijelo NN 388 je 1997. identificirano kao Josip Drvodelić (1966.), vozač radnih strojeva iz Donjeg Komareva. Civil. Dana 27. srpnja 1991., dok je

$\overline{10}$ Iz Radne grupe za lociranje, ekshumaciju i identifikaciju civilnih i vojnih žrtava rata ušli su: pukovnik Ivan Grujić - predsjednik Komisije za zatočene i nestale Vlade RH, Višnja Bilić članica Komisije, natporučnik Marko Miloš - povjerenik Komisije, Slavko Radoš - predstavnik MORH-a (Odjel za skrb). Iz Policijske uprave sisačko-moslavačke (dalje: PUSM): Nikola Vidović, Drago Pavlović, Damir Kolar, Marijan Gregurinčić, Ramiz Hodžić, Dubravko Pavušek, Elvir Šehić. Iz PP H. Kostajnica Dražen Grgurić. Iz Županijskog suda Sisak: predsjednik Suda Josip Budinski i zapisničarka Ljerka Kolarić. Prisustvovali su promatrač Europske zajednice (dalje: EZ) Werner Zofal i prevoditelj Davor Ričković.

11 MB-UZN-STOZNDR. Zapisnik Istražnog odjela Županijskog suda Sisak od 3. XI. 1997. KIR750/97., KIR-751/97., KIR-752/97., KIR-753/97., KIR-754/97., KIR-755/97., KIR-756/97. u predmetu provođenja istražnih radnji ekshumacija posmrtnih ostataka civilnih i vojnih žrtava rata na području općine $\mathrm{H}$. Kostajnica.

12 MB-UZN-STOZNDR. Zapisnik Zavoda za sudsku medicinu i kriminalistiku u Zagrebu (dalje: ZSMKZG) o pregledu i obdukciji tijela NN 387. s lokacije br. 1. Marveno groblje/Berek, od 3. XI. 1997.; Zapisnik ZSMKZG o pregledu i obdukciji tijela NN 388./Marveno groblje, od 11. XI. 1997.; Zapisnik ZSMKZG o pregledu i obdukciji tijela NN 389./Marveno groblje, od 11. XI. 1997.; Zapisnik ZSMKZG o pregledu i obdukciji tijela NN 390./Marveno groblje, od 11. XI. 1997.; Zapisnik ZSMKZG o pregledu i obdukciji tijela NN 391./Marveno groblje, od 11. XI. 1997.; Zapisnik ZSMKZG o pregledu i obdukciji tijela NN 392./Marveno groblje, od 11. XI. 1997.

13 MB-UZN-STOZNDR. Zapisnik ZSMKZG o identifikaciji tijela, od 22. IX. 2009. i Personalni dosje (dalje: PD) Kitonić Srećko br. 319. 
Jakša Raguž - Masovne grobnice u hrvatskom Pounju iz Domovinskog rata...

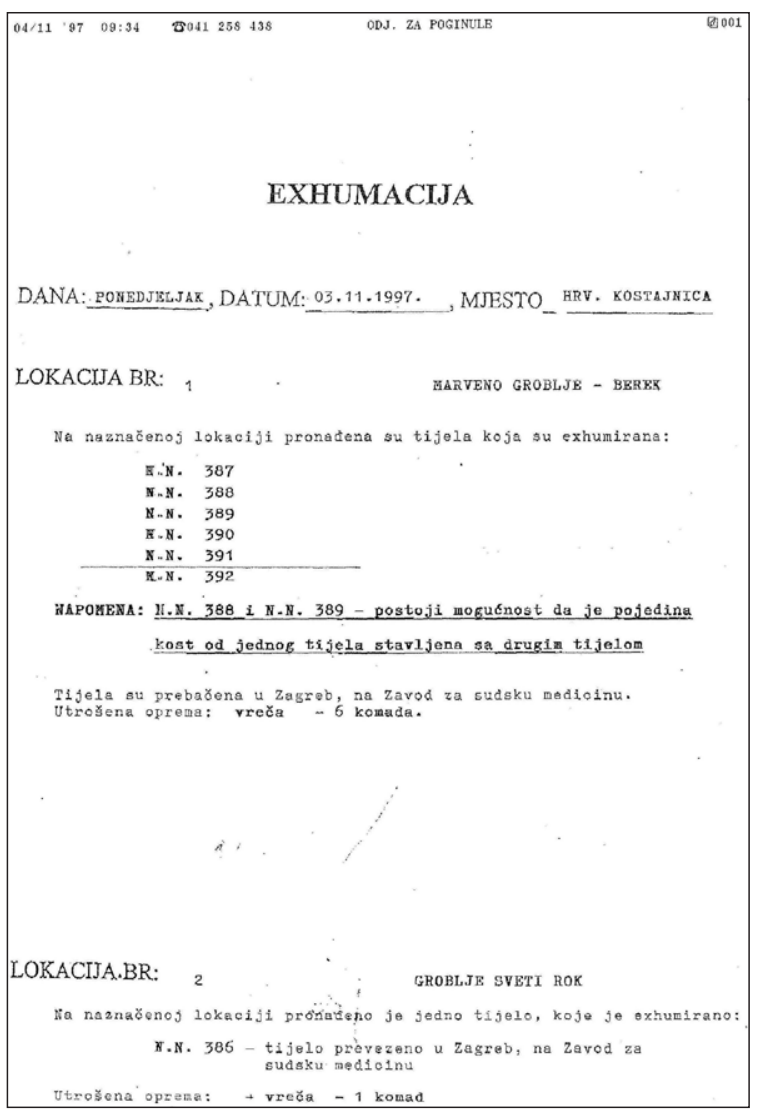

02 - Izvješće o ekshumaciji masovne grobnice Marveno groblje, prve masovne grobnice u Republici Hrvatskoj iz Domovinskog rata

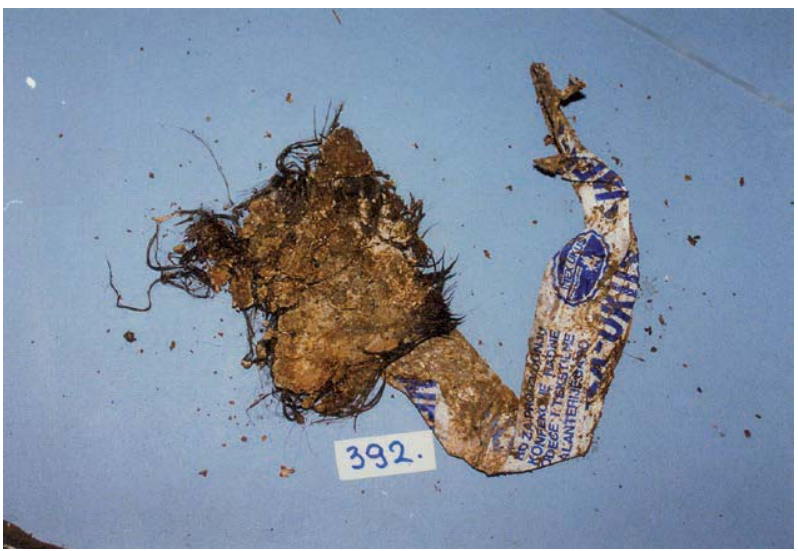

03 - Oko glave tj. na predjelu očiju, osobe NN 392 je nađena plastična samoljepljiva traka sa natpisom INEX UKUS - radna odjeća i galanterija Novi Beograd, sa ostacima čuperaka kose. 
vozio traktor, pobunjeni su ga Srbi iznad Blinjske Grede nasilno odveli u Veliku Gradusu. ${ }^{14}$

- tijelo NN 389 vodi se kao neidentificirano jer nije proveden cjelovit proces identifikacije. Na temelju usporedne analize DNK, načinjene na osnovi krvi M. H.-a, Zavod za sudsku medicinu i kriminalistiku dao je mišljenje da tijelo pripada Milanu Ivaniću, bratu M. H.-a. Milan (1965.) je bio radnik na zagrebačkom ranžirnom kolodvoru, iz Slovinaca. Civil. Sa suseljanima, braćom Mikulčić, 27. srpnja 1991. otet je u Slovincima, iz auta koji su pobunjenici zaustavili na cestovnoj barikadi. Nakon mučenja odvezeni su na Zrinsku goru. ${ }^{15}$ - tijelo NN 390 je 1998. identificirano kao Đuro Preporučeni (1964.), kadet Dunavskog Lloyda iz Komareva. Civil. Otet 27. srpnja između Komareva i Sunje. ${ }^{16}$ - tijelo NN 391 je 2003. identificirano kao Ivica Mikulčić (1970.), trgovac iz Slovinaca. Civil. Otet 27. srpnja 1991. s bratom Željkom i sumještaninom Milanom Ivanićem. Nakon mučenja odvezeni su prema Zrinskoj gori. ${ }^{17}$

- tijelo NN 392 je 2003. identificirano kao Željko Mikulčić (1969.), konobar iz Slovinaca. Civil. Otet 27. srpnja 1991. s bratom Ivicom i sumještaninom Milanom Ivanićem te nakon mučenja otpremljen na Zrinsku goru. ${ }^{18}$

Svim je žrtvama u grobnici zajedničko da se radi o mlađim neoženjenim muškarcima u dvadesetim godinama, hrvatske nacionalnosti i rimokatoličke vjere. Samo je jedan bio pripadnik hrvatskih oružanih snaga, ZNG-a, naoružan i zarobljen u oružanom sukobu. Ostala su petorica u trenutku nasilnog odvođenja bili nenaoružani civili. Osim gardista, svi su oteti u mjestima svog stalnog boravka ili u neposrednoj blizini i to 27. srpnja, drugoga dana srpske napadne operacije „Žaoka“, što ukazuje na to da se radi o koordiniranoj akciji.

\section{Slopačka kosa-Drainska kosa}

Udaljena sedam kilometara od kostajničkog sela Komogovine, a upravno na prostoru petrinjskog sela Pastuša, na lokaciji u središtu Zrinske gore, do koje se dolazi šumskim putom, nalazi se masovna grobnica Slopačka kosa-Drainska kosa. Ondje su, na uzvišenju udaljenom od šumskog puta oko 150 metara, pobunjeni Srbi krajem srpnja 1991. likvidirali sedmoricu civila iz glinske, kostajničke i petrinjske općine, otetih od 16. do 26. srpnja 1991. Zbog udaljenosti od naseljenih mjesta i zabačenosti dugo je trebalo dok se utvrdila lokacija grobnice. Otkrivena je

\footnotetext{
14 MB-UZN-STOZNDR. PD Drvodelić Josip br. 394.

15 MB-UZN-STOZNDR. PD Ivanić Milan br. 498.

16 MB-UZN-STOZNDR. PD Preporučeni Đuro br. 491.

17 MB-UZN-STOZNDR. PD Mikulčić Ivica br. 754. Anketa ispunjena po majci Ružici Mikulčić.

18 MB-UZN-STOZNDR. PD Mikulčić Željko br. 750. Anketa ispunjena po majci Ružici Mikulčić.
} 
tek 2002., kada ju je 27. i 28. lipnja 14-člana mješovita Radna grupa za lociranje, ekshumaciju i identifikaciju civilnih i vojnih žrtava rata ekshumirala. ${ }^{19}$ Pretragom terena na prostoru širine 4 x 4 metra u zemlji je nađeno 18 čahura metaka kalibra $7,62 \mathrm{~mm}$ vojnog podrijetla. Potom se pristupilo iskapanju, bagerom i ručno. Plitko, na dubini od 0,80 metara nađena su tijela sedmorice muškaraca te označena identifikacijskim brojevima u rasponu od NN 42 do NN 48. Tijela su uglavnom ležala na trbuhu; na nekima su već na prvi pogled bili uočljivi rupičasti defekti, a budući da su na širem području grobnice nađene čahure, zaključeno je da su strijeljana. Tijela su otpremljena u Zavod za sudsku medicinu i kriminalistiku u Zagreb kako bi se otkrio identitet. ${ }^{20}$ Obdukcije su pokazale da su sve žrtve stradale od strijelnih ozljeda iz vatrenog oružja, rafalnim ispaljivanjem metaka po cijelom tijelu. Tijela pojedinih žrtava bila su doslovce, ,izrešetana“ puščanim hicima, pa su im lubanje i dio kostiju bili razneseni i zdrobljeni, a u većini tijela nađena su zrna metaka. ${ }^{21}$ Do 2007. završena je identifikacija svih žrtava. Glede identiteta i statusa, on je sljedeći: - tijelo NN 42 je 2003. u Zavodu za sudsku medicinu metodom analize DNK identificirano kao Zvonko Govorčinović (1939.), tržišni inspektor iz Hrvatske Kostajnice. Civil. Pobunjenici su ga 26. srpnja 1991. oteli u zasjedi kod Šupljeg kamena i odvezli u Borojeviće. ${ }^{22}$

19 Iz Radne grupe za lociranje, ekshumaciju i identifikaciju civilnih i vojnih žrtava rata ušli su: pukovnik Ivan Grujić - predstojnik Ureda za zatočene i nestale Vlade RH, natporučnik Marko Miloš - povjerenik tog Ureda, brigadir Ante Vučić - predstavnik MORH-a, dr. Dražen Janković - vještak, patolog Opće bolnice „Dr. Ivan Pedišić“ Sisak, Izidor Škerc - pomoćnik pri obdukciji sa ZSMKZG-a. Iz PUSM-a: Zvonko Smerić, Elvir Šehić, Davor Kozina, Damir Kolar, Dražen Mićak i Ramiz Hodžić. Iz Županijskog suda Sisak: istražni sudac Ivica Pleše i zapisničarka Ljerka Kolarić. Prisustvovao je promatrač Međunarodne komisije za nestale osobe ICMP - Zagreb, Mladen Pem.

20 Arhiv Policijske uprave Sisačko-moslavačke (dalje: APUSM). K-28/03. Zapisnik Istražnog odjela Županijskog suda Sisak od 27. VI. 2002. KIR-394/02., KIR-413/02., KIR-414/02., KIR-415/02., KIR-416/02., KIR-417/02., KIR-418/02., KIR-419/02. u predmetu provođenja istražnih radnji ekshumacija posmrtnih ostataka civilnih i vojnih žrtava rata na području Sisačko-moslavačke županije.

21 MB-UZN-STOZNDR. Zapisnik ZSMKZG o pregledu i obdukciji posmrtnih ostataka s lokacije br. 1. Slopačka kosa/Drainska kosa (odjel 42a), tijelo NN 42., od 6. IX. 2002.; Zapisnik ZSMKZG o pregledu i obdukciji posmrtnih ostataka s lokacije br. 1. Slopačka kosa/Drainska kosa (odjel 42a), tijelo NN 43., od 6. IX. 2002.; Zapisnik ZSMKZG o pregledu i obdukciji posmrtnih ostataka s lokacije br. 1. Slopačka kosa/Drainska kosa (odjel 42a), tijelo NN 44., od 6. IX. 2002., PD Nogić Petar br. 724.; Zapisnik ZSMKZG o pregledu i obdukciji posmrtnih ostataka s lokacije br. 1. Slopačka kosa/Drainska kosa (odjel 42a), tijelo NN 46., od 20. IX. 2002.; Zapisnik ZSMKZG o pregledu i obdukciji posmrtnih ostataka s lokacije br. 1. Slopačka kosa/Drainska kosa (odjel 42a), tijelo NN 47., 6. IX. 2002.; Zapisnik ZSMKZG o pregledu i obdukciji posmrtnih ostataka s lokacije br. 1. Slopačka kosa/Drainska kosa (odjel 42a), tijelo NN 48., od 20. IX. 2002.

22 MB-UZN-STOZNDR. Zapisnik ZSMKZG o identifikaciji tijela, od 12. V. 2003. i PD Govorčinović Zvonko br. 1685. 
- tijelo NN 43 je 2003. u Zavodu metodom analize DNK identificirano kao Antun Kardaš (1931.), radnik Gavrilovića, nastanjen u selu Dragotinci u petrinjskoj općini. Civil. Lokalni pobunjenici odveli su ga iz kuće u Dragotincima 17. srpnja 1991. u Spomen-dom na Čavić brdu, gdje je bila pobunjenička baza. S njim su tada otpremljena i trojica zarobljenih pripadnika Ministarstva unutarnjih poslova (MUP) RH, od kojih je jedan, Đuro Lovreković, ekshumiran iz pojedinačnog groba. ${ }^{23}$

- tijelo NN 44 je 2003. identificirano DNK metodom kao Nikola Nogić(1931.), poslovođa u Hrvatskim željeznicama - Karlovac, iz glinskog sela Ravno Rašće. Civil. S bratom Petrom otet je u svojoj kući u Ravnom Rašću od pripadnika Milicije SAO Krajine 26. srpnja 1991. S još dvojicom mještana iz sela Maja, Petrom Pavićem i Perom Likovićem, zlostavljan je te isti dan otpremljen put Vlahovića, tj. Zrinske gore. ${ }^{24}$

- tijelo NN 45 je 2007. DNK metodom identificirano kao Petar Nogić(1933.), pružni radnik iz Ravnog Rašća. Civil. S bratom Nikolom i dvojicom mještana Maje otet je 26. srpnja 1991. iz Ravnog Rašća. ${ }^{25}$ Braća Nikola i Petar Nogić na udaru pobunjenih Srba bili su od ranije. Naime, 30. travnja 1991. skupina mještana Ravnog Rašća na autobusnoj stanici kod njihove kuće izvjesila je hrvatsku zastavu. Iako Nogići u tome nisu sudjelovali, u noći s 30. travnja na 1. svibnja 1991. pobunjenici su rafalno pucali na njihovu zajedničku kuću, misleći da su oni postavili zastavu. Tri su mjeseca nakon toga braća Nogić ubijena. ${ }^{26}$

- tijelo NN 46 je 2005. DNK metodom identificirano kao Petar Pavić(1930.), umirovljenik iz glinskog sela Maja. Civil. Pobunjeni su ga Srbi 26. srpnja 1991. oteli ispred trgovine obitelji Nogić u Ravnom Rašću i nakon mučenja odveli s još trojicom otetih civila put Zrinske gore. ${ }^{27}$

- tijelo NN 47 je 2003. DNK metodom identificirano kao Davor Pavlović (1960.), ekonomski tehničar iz Hrvatske Kostajnice. Civil. Davora, njegovu majku Anku Pavlović (1938.) i tetku Jelku Đurić (1927.) pobunjenici su 16. srpnja 1991. oteli u Veleškim poljima, dok su se autom vraćali iz obiteljskog posjeta. Otpremljeni su u Borojeviće, gdje su Davora odvojili i odveli u

23 MB-UZN-STOZNDR. Zapisnik ZSMKZG o identifikaciji tijela, od 12. V. 2003. i PD Kardaš Antun br. 372.

24 MB-UZN-STOZNDR. PD Nogić Nikola br. 1524.

MB-UZN-STOZNDR. PD Nogić Petar br. 724.

26 Hrvatski memorijalno-dokumentacijski centar Domovinskog rata (dalje: HMDCDR). Kutija Stanica milicije Glina-krivične prijave 1991. Kr. prijava PS Glina protiv nepoznatih počinioca kriv. djela ugrožavanja sigurnosti. Br. 511-10-30-Ku-40/91., od 4. V. 1991.

27 MB-UZN-STOZNDR. Zapisnik ZSMKZG o identifikaciji tijela, od 10. II. 2005. i PD Pavić Petar br. 445. 
Spomen-dom na Čavić brdu. I Anka Pavlović i Jelka Đurić likvidirane su te poslije rata ekshumirane iz pojedinačnih grobova. ${ }^{28}$

- tijelo NN 48 je 2007. DNK metodom identificirano kao Pero Liković (1940.), poljoprivrednik iz sela Maja. Civil. Pobunjenici su ga 26. srpnja 1991. oteli ispred trgovine obitelji Nogić u Ravnom Rašću. S braćom Nikolom i Petrom Nogićem te Petrom Pavićem tučen je i maltretiran u improviziranom zatvoru u podrumu, nakon čega su sva četvorica navedenih civila nasilno odvedena u Zrinsku goru i likvidirana. ${ }^{29}$

Ako se izuzme Davor Pavlović (1960.), svim je žrtvama u grobnici zajedničko da su muškarci u pedesetim i šezdesetim godinama. Sve su žrtve oženjene, hrvatske nacionalnosti i rimokatoličke vjeroispovijedi. U trenutku otmice svi su bili nenaoružani civili i svi su nasilno odvedeni iz mjesta stalnog boravka ili neposredne blizine. Dvojica su oteta ranije i zatočena u u Spomen-domu na Čavić brdu u pobunjeničkoj bazi, dok su petorica oteta 26. srpnja, prvog dana srpske napadne operacije „Žaoka“. Na osnovi podataka o lokacijama i vremenu nasilnog odvođenja te petorice žrtava, kao i materijalnih pokazatelja da su sedmorica žrtava istodobno likvidirana, može se zaključiti da je ova grobnica posljedica operacije „Žaoka“, čiji je cilj bilo zauzimanje Gline i Pounja, a koja se zbila od 26. do 31. srpnja 1991. Ta se grobnica mora razmatrati zajedno s grobnicom Marveno groblje, u kojoj su žrtve uglavnom otete 27. srpnja. Dakle, prema vremenu nastanka, masovne grobnice Slopačka kosa i Marveno groblje najstarije su na Banovini, a najvjerojatnije i u cijeloj Hrvatskoj. Nastale su gotovo istovremeno, od 26. do 28. srpnja 1991., likvidacijom dvanaestorice hrvatskih civila i jednog pripadnika ZNG-a, nasilno odvedenih s prostora od Sunje do Gline, što ukazuje da se radi o koordiniranoj akciji.

\section{Ulica Žrtava Domovinskog rata 2./Hrvatska Kostajnica (naselje Novljani)}

Iduća je grobnica u Pounju nastala 8. rujna 1991., za vrijeme napada pobunjenika na Hrvatsku Kostajnicu, kada se pred minobacačko-topničkim udarom i prodorom srpskog pješaštva hrvatska policija povukla iz sjevernog dijela grada. ${ }^{30} \mathrm{U}$ dijelu naselja Novljani pritom je ostao dio stanovnika, koji nije znao za povlačenje policije. Tako su se u kući na adresi Ulica žrtava fašističkog terora 2. (danas Ulica žrtava Domovinskog rata br. 2.) kod željezničke pruge zatekli pričuvni kostajnički policajac Mladen Bišćan, njegova supruga Anđelka Bišćan, njena majka starica

\footnotetext{
MB-UZN-STOZNDR. PD Pavlović Davor br. 447.

MB-UZN-STOZNDR. PD Liković Pero br. 448.

30 Arhiv Policijske uprave Zagreb (dalje: APUZ). Reg. 24. Zapisnik PS za sigurnost prometa o izjavi Oreški Dragana o boravku na ratištu H. Kostajnice, od 22. I. 1992.
} 
Jagoda Brkljačić, njihov petnaestogodišnji sin Danijel Bišćan i njihov susjed Gojko Badrić, inače srpske nacionalnosti. Ušavši u naselje, pobunjenici su opkolili i napali i ovu kuću. Budući da su bili naoružani, Mladen i Gojko su se branili. Nakon što je Gojko Badrić poginuo u kući, ostali su se odlučili predati jer su im pobunjenici obećali da će im poštedjeti živote. Nakon izlaska u dvorište Mladen i Anđelka Bišćan te Jagoda Brkljačić ubijeni su rafalom iz automatske puške, dok je dječak pošteđen. ${ }^{31}$ Pobunjenici su doveli zatočene hrvatske civile iz okolnih kuća da gledaju leševe poubijanih. Tijela su potom stavili na hrpu, polili naftom i zapalili. Nakon nekoliko dana pobunjenici su pokupili preostale nagorjele kosti pokojnika te ih s pobijenim domaćim životinjama zakopali u dvorištu. ${ }^{32}$

Zahvaljujući većem broju svjedoka, lokacija je ove masovne grobnice lako utvrđena, pa je 19. veljače 1997. u dvorištu kuće provedena ekshumacija od strane 13-člane mješovite Radne grupe. ${ }^{33}$ Nađena je veća količina izmiješanih kostiju s tragovima izloženosti vatri te nešto nagorjele obuće i odjeće. ${ }^{34}$ Analiza na Zavodu za sudsku medicinu i kriminalistiku u Zagrebu pokazala je da su to ostaci četiriju osoba, koje su dobile identifikacijske brojeve od 1 do 4 . Obdukcija je pokazala da su tri osobe umrle od višestrukih strijelnih rana, dok je od četvrte, starije žene, bilo tako malo ostataka da se nije mogao utvrditi uzrok smrti. ${ }^{35}$ Budući da su okolnosti stradanja bile poznate, identifikacija je brzo obavljena i to tzv. klasičnom metodom prepoznavanja. ${ }^{36}$ Glede identiteta i statusa, on je sljedeći:

- tijelo 1. identificirano je kao Mladen Bišćan (1944.) iz Hrvatske Kostajnice. Pripadnik pričuvnog sastava MUP-a. ${ }^{37}$

$\overline{31}$ APUSM. Reg. HK 38-75. Zapisnik ŽDOZ o ispitivanju Danijela Bišćana. Br. K-DO-311/12., od 16. V. 2013.

32 APUSM. Reg. HK 38-75. Zapisnik Okružnog suda Sisku o ispitivanju Milke I. Br:Kir-76/92., od 5. II. 1992.

33 Iz Radne grupe za lociranje, ekshumaciju i identifikaciju civilnih i vojnih žrtava rata ušli su: satnik Branko Bekavac - predstavnik MORH-a (Odjel za skrb), Marko Miloš - povjerenik Komisije za zatočene i nestale Vlade RH, dr. Krunoslav Jakovina - patolog, šef službe za patologiju i sudsku medicinu u Sl. Brodu, dr. Drinko Baličević - Zavod za kliničku patologiju bolnice „Sestara milosrdnica“. Iz PUSM-a: Nikola Vidović, Elvir Šehić i Alojzije Đuračić (kriminalistički tehničari). Iz PP H. Kostajnica: Goran Brebrić, Ramiz Hodžić, Mišel Balog i Dražen Grgurić. Iz Županijskog suda Sisak: predsjednik Suda Josip Budinski i zapisničarka Ljerka Kolarić. Ekshumaciji je prisustvovao promatrač EZ-a Werner Zofal, uz prevoditelja Sinišu Špana.

34 MB-UZN-STOZNDR. Zapisnik Istražnog odjela Županijskog suda u Sisku od 19. II. 1997. KIR-132/97., KIR-133/97., KIR-134/97., KIR-333/99., KIR-135/97. u predmetu provođenja istražnih radnji ekshumacije posmrtnih ostataka civilnih i vojnih žrtava rata na području općine Kostajnica.

35 MB-UZN-STOZNDR. Zapisnik ZSMKZG povodom identifikacije posmrtnih ostataka iz H. Kostajnice, lok. 1. Ulica žrtava Domovinskog rata k. br. 2., od 19. II. 1997.

36 MB-UZN-STOZNDR Zapisnik ZSMKZG o identifikaciji mrtvih tijela sa lok. H. Kostajnica, od 23. IV. 1997.

37 MB-UZN-STOZNDR. PD Bišćan Mladen. 
- tijelo 2. identificirano je kao Gojko Badrić (1929.) iz Hrvatske Kostajnice. Hrvatski branitelj nedefiniranog statusa. ${ }^{38}$

- tijelo 3. identificirano je kao Anđelka Bišćan (1951.) iz Hrvatske Kostajnice. Civil. ${ }^{39}$

- tijelo 4. identificirano je kao Jagoda Brkljačić (1926.) iz Hrvatske Kostajnice. Civil. ${ }^{40}$

Žrtve su po svom statusu, dobi, spolu i etničkoj pripadnosti vrlo raznolike. Dvije su žrtve pripadnici hrvatskih obrambenih struktura, a dvije civili, dvije su srednje, a dvije starije životne dobi, dvije su muškog, a dvije ženskog spola. Ovo je kronološki prva grobnica u Pounju u koju su ukopane i ženske osobe. Tri su žrtve hrvatske, a jedna srpske nacionalnosti. Jedna je poginula u oružanom sukobu, a tri su strijeljane pri predaji. Ovakav odnos prema zarobljenicima iz bitke za Hrvatsku Kostajnicu srpski će pobunjenici provoditi i dalje te su, nakon pada grada, 12. rujna 1991., nastale još tri masovne grobnice ratnih zarobljenika.

\section{Kurbanovo brdo/Hrvatska Kostajnica}

Prema podacima koje je PU sisačko-moslavačka dobila od Steve K., na Kurbanovu brdu, na istočnom rubu Hrvatske Kostajnice pokopana su tijela trojice hrvatskih policajaca. Nakon dobivanja informacije planiralo se da se u lipnju 1999. provede iskapanje. ${ }^{41}$ Već u sklopu pripremnih radnji nastao je tehnički problem jer se zbog strmog terena bager nije mogao popeti na lokaciju. ${ }^{42}$ Stoga je tek 2. rujna 1999., na mjestu koje je dobilo naziv Lokacija br. 1. Hrvatska Kostajnica/Kurbanovo brdo, ekshumaciju provela 13-člana mješovita Radna grupa. ${ }^{43}$ Iskapanje se vršilo strojno te su na dvjema lokacijama, međusobno udaljenima 12 metara, nađeni ostaci četiriju ljudskih tijela. Na prvoj su lokaciji nađena tri

\footnotetext{
38 MB-UZN-STOZNDR. PD Badrić Gojko

42 MB-UZN-STOZNDR. Zapisnik Istražnog odjela Županijskog suda Sisak od 7. VI. 1999. KIR341/99. u predmetu provođenja istražnih radnji ekshumacije posmrtnih ostataka civilnih i vojnih žrtava rata na području Sisačko-moslavačke županije.

43 Iz Radne grupe za lociranje, ekshumaciju i identifikaciju civilnih i vojnih žrtava ušli su: pukovnik Ivan Grujić - predsjednik Komisije za zatočene i nestale Vlade RH, natporučnik Marko Miloš - povjerenik te Komisije, satnik Branko Bekavac - predstavnik MORH-a (Odjel za ekshumaciju), dr. Drinko Baličević sa Zavoda za kliničku patologiju bolnice „Sestara milosrdnica“. Iz PUSM-a: Zlatko Krušić, Goran Dolovčak, Drago Pavlović, Elvir Šehić, Miljenko Bošnjak, Dubravko Pavušek, Marijan Gregurinčić i Damir Kolar. Iz PS H. Kostajnica Dražen Grgurić. Iz Županijskog suda Sisak: predsjednik Suda Josip Budinski i zapisničarka Ljerka Kolarić. Prisustvovali su promatrač EZ-a Ahti Virolainen i prevoditeljica Iva Papac.
} 
tijela, od kojih su dva ležala jedno preko drugog, a treće pored njih. Tijela su bila odjevena u ostatke policijskih odora, s policijskim značkama i nizom osobnih stvari, a uz dva su nađeni i dokumenti na imena Ivana Leškovića i Ivice Šnjarića. Ta su tri tijela dobila identifikacijske brojeve od NN 133 do NN 135. Cetvrto tijelo, koje je dobilo identifikacijski broj NN 136, nađeno je udaljeno 12 metara od prve jame i to u obliku razasutih fragmenata kostura, posve ogoljelih, a brojni su dijelovi nedostajali. ${ }^{44}$

$\mathrm{Na}$ Zavodu za sudsku medicinu i kriminalistiku obdukcijom je utvrđeno da su uzroci smrti triju žrtava s prve lokacije veći broj strijelnih rana glava i tijela, tj. da su bile strijeljane. Za četvrto tijelo NN 136 utvrđeno je da se radi o odraslom muškarcu. Na temelju izgleda kostiju zaključeno je kako nije iz razdoblja Domovinskog rata, već je iz nekog starijeg razdoblja. Iz tog razloga identifikacija nije bila moguća ${ }^{45}$ Glede identiteta i statusa žrtava, on je sljedeći:

- tijelo NN 134 je 1999. na Zavodu identificirano kao Ivan Lešković (1967.) iz Zagreba, radnik zagrebačke uljare Crvena zvijezda. Kao pričuvni policajac PU Zagreb - Policijske stanice (PS) Maksimir-Pešćenica, u rujnu 1991. poslan je u obranu Hrvatske Kostajnice. ${ }^{46}$ Prema dostupnim podacima, 10. rujna 1991. ranjen je na položaju na brdu Djed i otpremljen u improviziranu bolnicu u zgradi pošte, gdje je zadržan na liječenju. ${ }^{47}$

- tijelo NN 135 je 1999. na Zavodu identificirano kao Ivica Šnjarić (1962.) iz Zagreba, strojarski tehničar u rafineriji INA-e. Kao pričuvni policajac PU Zagreb - PS za sigurnost prometa, u rujnu 1991. poslan je u obranu Hrvatske Kostajnice. ${ }^{48} \mathrm{Na}$ dan pada grada, 12. rujna 1991., bio je na položaju „Pounje“ na istočnom rubu grada. Postoje indicije da je s još nekolicinom policajaca krenuo u proboj u pravcu Hrvatske Dubice. ${ }^{49}$

44 MB-UZN-STOZNDR. Zapisnik Istražnog odjela Županijskog suda Sisak od 1. IX. 1999. KIR471/99., 472/99., 473/99., 474/99., 475/99. u predmetu provođenja istražnih radnji ekshumacije posmrtnih ostataka civilnih i vojnih žrtava rata na području općina Petrinja, H. Kostajnica i Novska.

45 MB-UZN-STOZNDR. Protokol ZSMKZG o obdukciji tijela NN 133. s lok. 1. H. Kostajnica, od 14. IX. 1999.; Protokol ZSMKZG o obdukciji tijela NN 134. s lok. 1. H. Kostajnica, od 14. IX. 1999.; Protokol ZSMKZG o obdukciji tijela NN 135. s lok. 1. H. Kostajnica, od 14. IX. 1999.; Protokol ZSMKZG o obdukciji tijela NN 136. s lok. 1. H. Kostajnica, od 14. IX. 1999.

46 MB-UZN-STOZNDR. Zapisnik ZSMKZG o identifikaciji mrtvih tijela s lok. br. 1. H. Kostajnica, od 23. IX. 1999., PD Lešković Ivan br. 638. APUZ. Reg. 26. Bilješke o sudbini šest djelatnika PUZ-a, nedatirano.

48 MB-UZN-STOZNDR. Zapisnik ZSMKZG o identifikaciji mrtvih tijela s lok. br. 1. H. Kostajnica, od 23. IX. 1999., PD Šnjarić Ivica br. 136.

49 MB-UZN-STOZNDR. PD Šnjarić Ivica br. 136. Sl. zabilješka PUZ - Odjel ratnih zločina i terorizma o saznanjima obitelji o nestalom Šnjarić Ivice, u potpisu Željko Mikulić, u prilogu Dopisa MUP-a Sektor kriminalističke policije/Odjela ratnih zločina i terorizma. Br. 511-0122/3-36678/98., od 25. V. 1998. 
- tijelo NN 133, muškarca starog između 27 i 34 godina, visokog oko $173 \mathrm{~cm}$, odjevenog u ostatke policijske odore, koji je preminuo od ozljeda mozga i lijeve nadlaktice, ostalo je neidentificirano. ${ }^{50}$

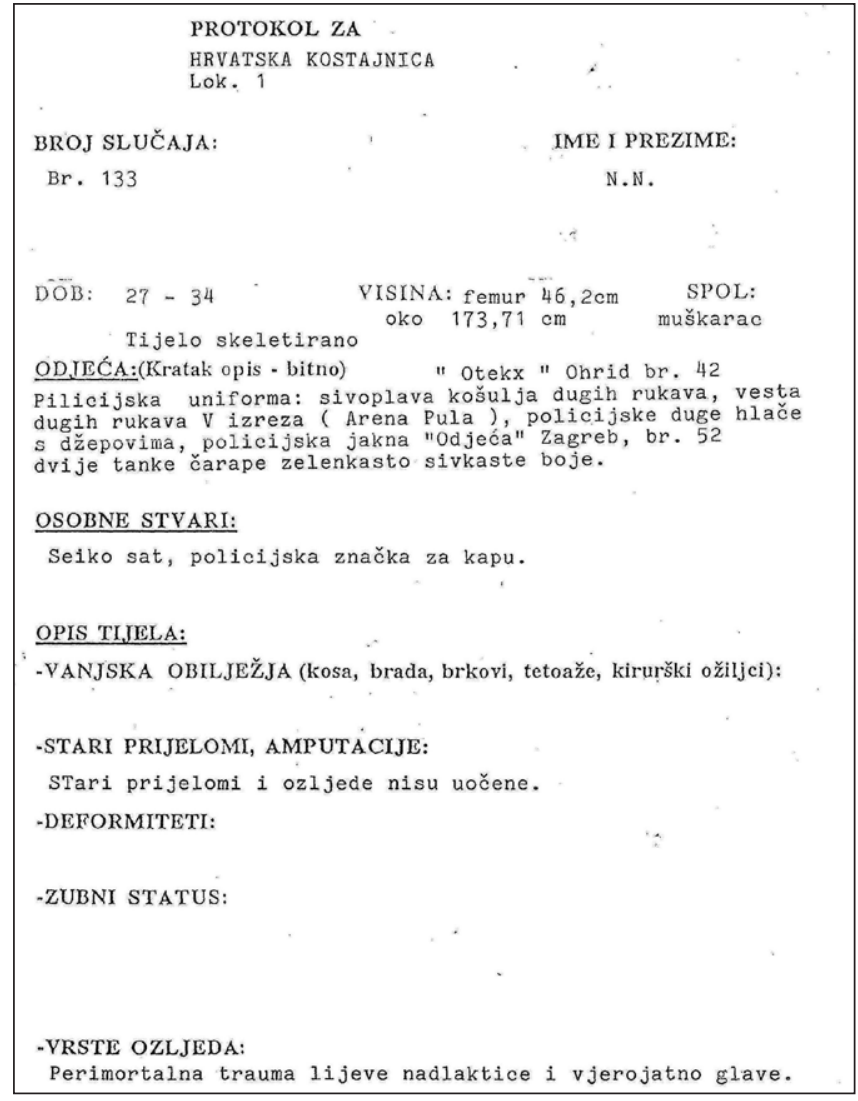

04 - Primjer slučaja neidentificirane osobe iz masovne grobnice Kurbanovo brdo

Glede žrtava iz te grobnice, za sve se tri žrtve iz prve jame može potvrditi da su bile pripadnici hrvatske policije, muškarci mlađe dobi. Za dvojicu je poznato da su bili pričuvni policajci iz Zagreba, mobilizirani i poslani na kostajničko bojište. Obojica su bila oženjena i imala djecu, Hrvati, rimokatolici. Veći broj strijelnih rana na tijelima sve trojice ukazuje da su najvjerojatnije bili zarobljeni i strijeljani 12. rujna 1991., tj. u trenutku srpske okupacije grada.

$\overline{50}$ MB-UZN-STOZNDR. Protokol ZSMKZG o obdukciji tijela NN 133. s lok. 1. H. Kostajnica, od 14. IX. 1999. 


\section{Bašćine/Donji Hrastovac}

U selu Donji Hrastovac, udaljenom 500 metara s desne strane magistralne ceste Sunja - Hrvatska Kostajnica, na močvarnom je polju Bašćine masovna grobnica osmorice hrvatskih policajaca i civila, koji su ondje dovedeni i likvidirani nakon pada Hrvatske Kostajnice, u noći s 12. na 13. rujna 1991.

Godinama nakon oslobođenja djelatnici PU sisačko-moslavačke na širem su području Donjeg Hrastovca tražili masovnu grobnicu. Tako je 9. svibnja 1997. izvršeno iskapanje na livadi Maina, gdje se očekivalo da će se naći masovna grobnica zarobljenika iz Hrvatske Kostajnice. No, ništa nije pronađeno. ${ }^{51}$ Nakon tog prvog, neuspjelog iskapanja, policija je intenzivirala rad. Budući da se zakopavanje tijela izvršilo javno, dosta je mještana Donjeg Hrastovca znalo za lokaciju grobnice, ali su se bojali reći ili su samo okvirno navodili mjesto. ${ }^{52}$ Neki su zbog rodbinskih ili prijateljskih veza s počiniteljima zločina tvrdili da ništa ne znaju..$^{53}$ Nakon dvogodišnje istrage PU je, prema iskazu svjedoka koji je pokazao lokaciju, doznala da bi na lokalitetu Bašćine trebala biti ukopana tijela osam ubijenih osoba - petorice policajaca i trojice civila. Djelatnici Odjela za suzbijanje terorizma PU sondirali su lokaciju i našli jednu ljudsku kost. ${ }^{54}$

Na temelju toga 13-člana mješovita Radna grupa ${ }^{55}$ 7. i 8. lipnja 1999. izvela je iskapanje na Bašćinama i našla osam skerletiranih, dijelom saponificiranih tijela, koja su dobila identifikacijske brojeve od NN 109 do NN 116. Grobnica je izgledala kaotično. Kosti i lubanje bile su polomljene i izmiješane, dijelovi tijela otkinuti i razbacani po jami. Svim su žrtvama ruke bile vezane na leđima debelom žicom, dvožilnim kabelom, policijskim lisicama ili kožnim remenom, a kod nekih su

$\overline{51}$ MB-UZN-STOZNDR. Zapisnik Istražnog odjela Županijskog suda Sisak od 9. V. 1997. KIR359/97. u predmetu provođenja istražnih radnji ekshumacija posmrtnih ostataka žrtava rata na području općine Sunja.

52 APUSM. K-25/99. Sl. bilješka PP Sunja o obavj. razgovoru sa Stevom M., od 14. XI. 1997.; Sl. bilješka PP Sunja o razgovoru s Olgom M. od 4. VI. 1997.; Sl. bilješka PP Sunja o razgovoru s Milkom S., od 10. IX. 1998.

53 APUSM. K-25/99. Sl. bilješka PP Sunja o obavj. razgovoru s Gojkom P., od 24. XI. 1998.; S1. bilješka PUZ-a o inf. razgovoru sa Sarom B. od 17. VI. 1998.

54 MB-UZN-STOZNDR. Prijedlog lokacija za ekshumacije i za probna iskapanja Odjela krimpolicije PUSM. Br. 511-10-04/04-1381-4/99., od 3. V. 1999.

55 Iz Radne grupe za lociranje, ekshumaciju i identifikaciju civilnih i vojnih žrtava rata ušli su: pukovnik Ivan Grujić - predsjednik Komisije za zatočene i nestale Vlade RH, natporučnik Marko Miloš - povjerenik Komisije, satnik Branko Bekavac - predstavnik MORH-a (Odjel za ekshumaciju), dr. Drinko Baličević sa Zavoda za kliničku patologiju bolnice „Sestara milosrdnica“. Iz PUSM-a: Nikola Vidović, Drago Pavlović, Damir Kolar, Marijan Gregurinčić, Ramiz Hodžić, Dubravko Pavušek i Elvir Šehić. Iz PP H. Kostajnica Dražen Grgurić. Iz Županijskog suda Sisak: predsjednik Suda Josip Budinski i zapisničarka Ljerka Kolarić. Promatrači EZ-a: Tore Flennfeldt, Ernesto Gaschino, Artur Sobierajski, Ciriaco Rapa, Karl Walter Stengel. Prevoditeljice: Snježana Vrhovec i Željka Turčin. 
oko glave nađeni ostaci ljepljive plastične trake, koja je pokrivala usta. Za pet je žrtava utvrđeno da su pri pogubljenju bile gole ili samo u donjem rublju te bose, dok su na trima nađeni ostaci civilne odjeće. ${ }^{56}$ Tijela su prevezena na Zavod za sudsku medicinu i kriminalistiku u Zagrebu, gdje je za većinu žrtava utvrđeno da su uzrok smrti strijelne rane glave, dok su na nekima nađene teške ozljede i na tijelu. ${ }^{57}$ Tijekom 1999. utvrđen je identitet svih žrtava. Treba napomenuti da su po etničkoj i vjerskoj pripadnosti sedam žrtava Hrvati, rimokatolici:

- tijelo NN 109 identificirano je kao Ivica Škacan (1937.), radnik drvne industrije iz Hrvatske Kostajnice. Civil. S braćom Bojanovski 10. rujna 1991. otet je u selu Tirol. ${ }^{58}$

- tijelo NN 110 identificirano je kao Željko Bjelić (1963.) iz Zagreba, djelatni policajac PU Zagreb - PS Sesvete. Srbin, pravoslavac. U rujnu 1991. poslan je u obranu Hrvatske Kostajnice. Kao zapovjednik III. voda pričuvne policije s više je policajaca zarobljen 12. rujna. ${ }^{59}$

- tijelo NN 111 DNK metodom identificirano je kao Dražen Pereglin (1970.) iz Sesveta, tehničar metalske struke. Kao pričuvni policajac PU Zagreb - PS Maksimir-Pešćenica, mobiliziran je u rujnu 1991. i poslan u obranu Hrvatske Kostajnice. Pri padu grada zarobljen je sa skupinom policajaca. ${ }^{60}$

- tijelo br. NN 112 identificirano je kao Božan Miloš (1966.) iz Sesveta, djelatni policajac PU Zagreb - PS Maksimir-Pešćenica. Pri padu Hrvatske Kostajnice 12. rujna 1991. zarobljen je sa skupinom policajaca. ${ }^{61}$

$\overline{56}$ APUSM. K-25/99. Zapisnik Istražnog odjela Županijskog suda Sisak od 7. VI. 1999. KIR330/99., KIR-331/99., KIR-332/99., KIR-333/99., KIR-334/99., KIR-335/99., KIR-336/99., KIR-337/99. u predmetu provođenja istražnih radnji ekshumacije posmrtnih ostataka civilnih i vojnih žrtava rata na području Sisačko-moslavačke županije.

57 MB-UZN-STOZNDR. Protokol ZSMKZG o obdukciji tijela NN 109. s lok. 1. Baščine/Hrastovac. Sp. 64.258-629/99., od 21. VII. 1999.; Protokol ZSMKZG o obdukciji tijela NN 110. s lok. 1. Baščine/Hrastovac. Sp. 64.257-628/99., od 21. VII. 1999.; Protokol ZSMKZG o obdukciji tijela NN 111. s lok. 1. Baščine/Hrastovac. Sp. 64.503-874/99., od 13. X. 1999.; Protokol ZSMKZG o obdukciji tijela NN 112. s lok. 1. Baščine/Hrastovac. Sp. 64.277-646/99., od 27. VII. 1999.; Protokol ZSMKZG o obdukciji tijela NN 113. s lok. 1. Baščine/Hrastovac. Sp. 64.502-873/99., od 27. VII. 1999.; Protokol ZSMKZG o obdukciji tijela NN 114. s lok. 1. Baščine/Hrastovac. Sp. 64.604-975/99., od 25. XI. 1999.; Protokol ZSMKZG o obdukciji tijela NN 115. s lok. 1. Baščine/Hrastovac. Sp. 64.259-630/99., od 21. VII. 1999.; Protokol ZSMKZG o obdukciji tijela NN 116. s lok. 1. Baščine/Hrastovac Sp. 64.260-631/99., od 21. VII. 1999.

58 APUSM. K-25/99. Zapisnik ZSMKZG o identifikaciji s lok. 1. Hrastovac, tijelo NN 109., od 21. VII. 1999. i MB-UZN-STOZNDR. PD Škacan Ivica.

59 APUSM. K-25/99. Zapisnik ZSMKZG o identifikaciji s lok. 1. Hrastovac, tijelo NN 110., od 21. VII. 1999. i PD Bjelić Željko br. 1799.

60 APUSM. K-25/99. Zapisnik ZSMKZG o identifikaciji tijela NN 111. s lok. 1. Hrastovac, od 13. X. 1999. MB-UZN-STOZNDR. PD Pereglin Dražen br. 644.

${ }^{61}$ APUSM. K-25/99. Zapisnik ZSMKZG o identifikaciji tijela NN 112. s lok. 1. Hrastovac, od 27. VII. 1999. i PD Miloš Božan br. 1824. 
- tijelo NN 113 s pomoću DNK metode identificirano je kao Zdravko Majta (1968.) iz Zagreba, analitičar živežnih namirnica. Kao pričuvni policajac PU Zagreb - PS Maksimir-Pešćenica u rujnu 1991. poslan je u obranu Hrvatske Kostajnice. Zarobljen je sa skupinom policajaca. ${ }^{62}$

- tijelo NN 114 s pomoću DNK metode identificirano je kao Đuro Živko (1956.) iz Zagreba, električar. Kao pričuvni policajac PU Zagreb - PS za sigurnost prometa u rujnu 1991. poslan je u obranu Hrvatske Kostajnice. Zarobljen je u rovu sa skupinom policajaca. ${ }^{63}$

- tijelo NN 115 identificirano je kao Franjo Bojanovski (1940.), građevinski radnik iz kostajničkog sela Tirol. Civil. S bratom Antunom i Ivom Škacanom otet je 10. rujna 1991. u Tirolu od lokalnih srpskih pobunjenika. ${ }^{64}$

- tijelo NN 116 identificirano je kao Antun Bojanovski (1933.), umirovljeni krojač iz Tirola. Civil. S bratom Franjom i kumom Ivom Škacanom otet je u vlastitoj kući u Tirolu od lokalnih srpskih pobunjenika. ${ }^{65}$

Istraga je pokazala da su policajci zarobljeni 12. rujna 1991. u rovu na položaju „Pounje“, sjeveroistočno od grada, i otpremljeni u zatvor u Srednju Meminsku. Nakon ispitivanja, zajedno s trojicom odranije zatočenih kostajničkih civila, isti su dan otpremljeni u Donji Hrastovac. ${ }^{66}$ Ondje su mučeni. Mještani su sela u noći satima slušali njihovo vrištanje i zapomaganje.${ }^{67}$ Nakon toga su likvidirani, a tijela su im sutradan pred gotovo cijelim stanovništvom sela pokopana u grobnicu grajfer utovarivačem (manja bagerska žlica koja se priključi na traktor i koristiti za kopanje). Budući da je zemlja, ilovača, bila tvrda, iskopana je plitka jama, u koju tijela nisu mogla stati. Stoga ih se grajferom gnječilo i nabijalo u jamu. Iz tog su razloga tijela smrskana i raskomadana, kako su i nađena pri ekshumaciji. ${ }^{68}$

Ova je grobnica po vrsti žrtava heterogena. Čine je petorica zagrebačkih policajaca, dvojica djelatnih i trojica pričuvnih, mobiliziranih, te trojica civila iz Hrvatske Kostajnice. Četvorica policajaca bila su mlađe dobi, jedan srednje,

62 APUSM. K-25/99. Zapisnik ZSMKZG o identifikaciji tijela NN 113. s lok. 1. Hrastovac, od 13. X. 1999. i PD Majta Zdravko br. 645.

63 APUSM. K-25/99. Zapisnik ZSMKZG o identifikaciji tijela NN 114. s lok. 1. Hrastovac, od 29. XI. 1999. i MB-UZN-STOZNDR. PD Živko Đuro br. 1837.

64 APUSM. K-25/99. Zapisnik ZSMKZG o identifikaciji tijela NN 115. s lok. 1. Hrastovac, od 21. VII. 1999. MB-UZN-STOZNDR. PD Bojanovski Franjo br. 635.

65 APUSM. K-25/99. Zapisnik ZSMKZG o identifikaciji tijela NN 116. s lok. 1. Hrastovac, od 21. VII. 1999. i MB-UZN-STOZNDR. PD Bojanovski Antun br. 662.

66 APUSM. K-25/99. Zapisnik Okružnog suda Beograd o ispitivanju Milorada B. Kri.V74/2008., 5. IX. 2008.

67 APUSM. K-25/99. S1. bilješka PP Sunja o obavj. razgovoru s Đorđem D., od 14. IX. 1998. i Sl. bilješka PP Sunja o obavj. razgovoru s Olgom M. od 4. VI. 1997.

68 APUSM. K-25/99. Zapisnik Županijskog suda Sisak o ispitivanju Miloša J. Kio-26/00., od 28. IX. 2004. 


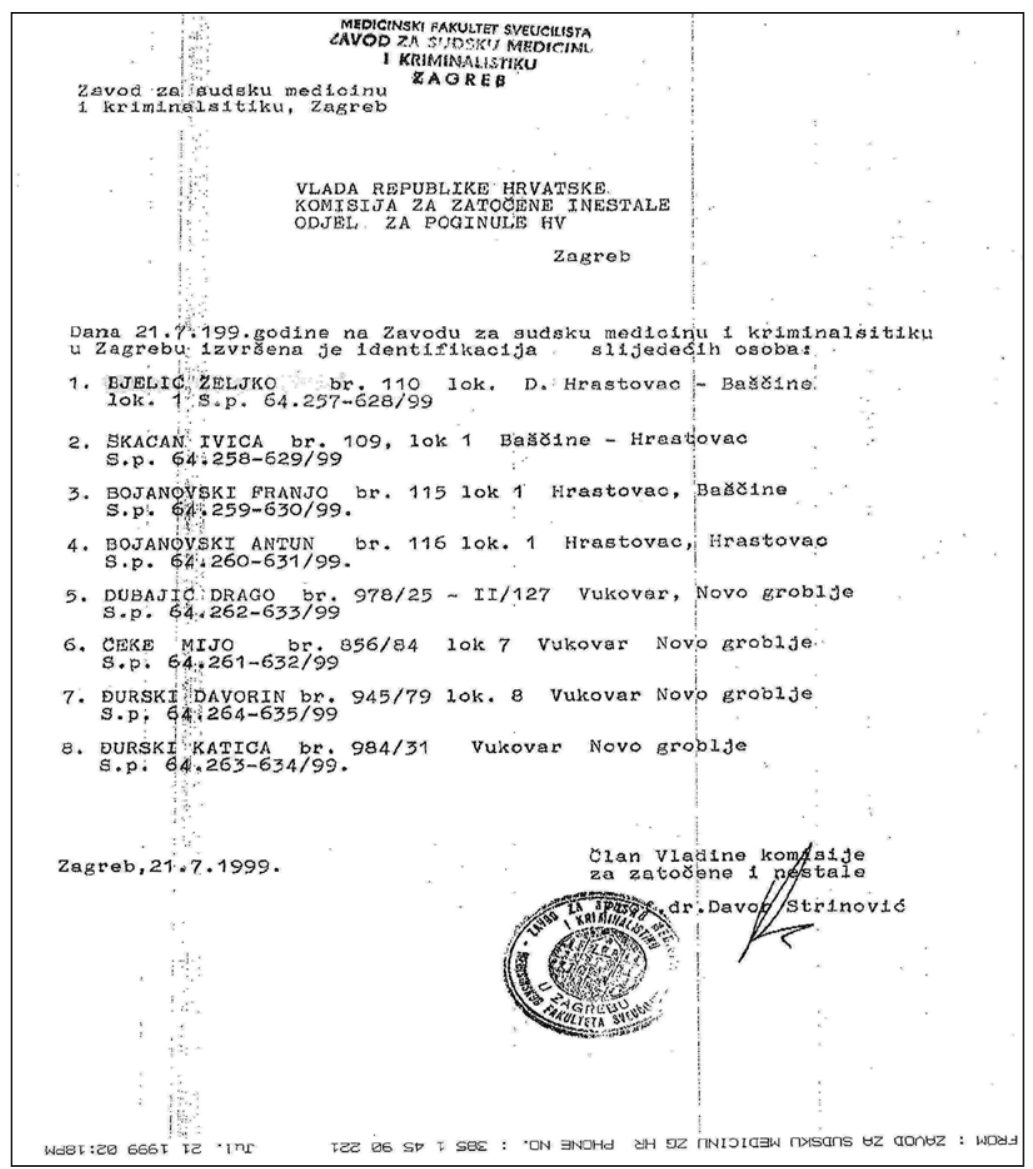

05 - Primjer uspješne identifikacije skupine žrtava iz masovne grobnice Bašćine

a sva su trojica civila bila starije dobi. Dvije su žrtve bile neoženjene, a sve ostale imale su djecu. Etnički je sedam žrtava bilo hrvatske, a jedna srpske nacionalnosti. Nijedna žrtva nije stradala u borbi, već su planski likvidirane nakon zarobljavanja.

\section{Plavićevac/Mečenčani}

Nedaleko od sela Mečenčani, u kanjonu potoka Plavićevca, blizu starog lovačkog doma, a u šumi Plavićevac, nalazi se masovna grobnica nastala likvidacijom deset osoba, koje su srpske postrojbe zarobile pri padu Hrvatske Kostajnice na brdu Djed, odnosno koje su se lokalnim Srbima predale na unskom mostu između Hrvatske i Bosanske Kostajnice. Komisija Vlade RH za zatočene i nestale još se u ratu, na pregovorima sa srpskom stranom, propitivala o sudbini nestalih zarobljenika iz Hrvatske Kostajnice, no nije dobila odgovor. Poslije oslobođenja 
Banovine policija je operativnim radom doznala za više lokacija na kojima bi oni mogli biti pokopani. Izvršeno je i nekoliko neuspješnih probnih iskapanja. ${ }^{69}$ Godine 1996. u Republiku Hrvatsku ilegalno je ušao M. R. iz sela Prevršac. Od njega su kostajnički policajci doznali za Plavićevac. Precizno je opisao lokaciju - gdje je kopana zemlja i stablo propucano mecima. Drugih podataka, o žrtvama i počiniteljima, nije znao. U PU sisačko-moslavačkoj procijenili su da bi ondje mogla biti pokopana tijela zarobljenika iz Hrvatske Kostajnice. ${ }^{70}$ Nakon što su probnim iskapanjem nađeni dijelovi ljudskih tijela, 29. travnja 1997. počeli su ekshumacijski radovi. Budući da je teren bio jako težak (močvaran i vlažan s podzemnim vodama), radovi Radne grupe za ekshumaciju dugo su trajali, do 7. svibnja. ${ }^{71} \mathrm{U}$ tom je periodu iskopano deset tijela, koja su dobila identifikacijske brojeve NN 178 te potom u nizu od NN 181 do NN 189. Tijela su otpremljena na Zavod za sudsku medicinu i kriminalistiku u Zagrebu. Obdukcije su pokazale da je svih deset osoba umrlo od strijelnih rana, tj. da su pogubljene strijeljanjem. ${ }^{72}$

Na nekim je tijelima nađeno više ozljeda i teških lomova kostiju, nastalih prije smrti, vjerojatno kao posljedica mučenja, te povezi oko očiju. Dio tijela bio je odjeven u ostatke policijskih i maskirnih odora, a dio u civilnu odjeću, s brojnim vidljivim okruglastim defektima, nastalima od puščanih hitaca. I u tijelima su pri obdukciji nađeni meci. U odjeći je nađeno više predmeta te dokumenti Davorina Briševca. ${ }^{73}$ Postupak identifikacije bio je dugotrajan te je okončan tek 2009. Glede identiteta i statusa, on je sljedeći:

69 MB-UZN-STOZNDR. PD Radić Damir br. 2766. Dopis Komisije Vlade RH za zatočene i nestale. Ur. br: 50412-97-3729., od 30. X. 1997.

70 Arhiv Županijskog državnog odvjetništva Sisak (dalje: AŽDOS). Spis KN-DO-28/04. S1. zabilješka PP H. Kostajnica o obav. razgovoru s Igorom T. Br. 511-10-15-03-2628/04., od 10. XII. 2004. i MB-UZN-STOZNDR. Dopis PUSM o lokacijama preostalima za ekshumacije. Br. 511-10-04/04-3880/97. ZS., od 16. IV. 1997.

${ }^{71}$ Iz Radne grupe za lociranje, ekshumaciju i identifikaciju civilnih i vojnih žrtava rata ušli su: pukovnik Ivan Grujić - predsjednik Komisije za zatočene i nestale Vlade RH, natporučnik Marko Miloš - povjerenik te Komisije, satnik Branko Bekavac - predstavnik MORH-a (Odjel za ekshumaciju), dr. Drinko Baličević sa Zavoda za kliničku patologiju bolnice „Sestara milosrdnica“. Iz PUSM-a: Nikola Vidović, Elvir Šehić, Alojzije Đuračić, Ramiz Hodžić i Davor Cvetnić. Iz PP H. Kostajnica Dražen Grgurić. Iz Županijskog suda Sisak: predsjednik Suda Josip Budinski i zapisničarka Ljerka Kolarić. Prisustvovali su promatrači EZ-a Werner Zofal i Kramb Jochen te prevoditelj Davor Ričković.

72 AŽDOS. Spis KN-DO-28/04. Zapisnik Istražnog odjela Županijskog suda Sisak od 29. IV. 1997. KIR-320/97., KIR-333/97., KIR-343/97., KIR-346/97., KIR-347/97., KIR-348/97., KIR-349/97., KIR-350/97., KIR-351/97., KIR-352/97. u predmetu provođenja istražnih radnji ekshumacija posmrtnih ostataka civilnih i vojnih žrtava rata na području općine H. Kostajnica i Analiza stanja predmeta KN-DO-28/04. ŽDOS od 12. XII. 2008.

73 AŽDOS. Spis KN-DO-28/04. Zapisnik ZSMKZG o pregledu i identifikaciji tijela NN 178./ Plavićevac. Br. Sp. 61.746-687/1997. od 16. V. 1997.; Zapisnik ZSMKZG o pregledu i identifikaciji tijela NN 181. /Plavićevac Br. Sp. 61.754-695/1997., od 16. V. 1997.; Zapisnik 
- tijelo NN 178 je 2009. DNK metodom identificirano kao Stipica Vukadin (1960.) iz Zagreba, inženjer prometnih znanosti. Kao pričuvni policajac PU Zagreb - PS za sigurnost prometa, u rujnu 1991. poslan je u obranu Hrvatske Kostajnice. Dana 12. rujna 1991. ranjen je i zarobljen na brdu Djed te je s drugim ranjenikom izdvojen iz zarobljeničke kolone. ${ }^{74}$

- tijelo NN 181 je 1999. DNK metodom identificirano kao Dražen Vujčić (1969.), djelatni policajac Policijske postaje (PP) Hrvatska Kostajnica. Nakon predaje na unskom mostu u Bosanskoj Kostajnici 12. rujna pobunjenici su ga odvojili od zarobljenika i odvezli na okupiranu hrvatsku obalu Une. ${ }^{75}$ - tijelo NN 182 je 1997. identificirano kao Davorin Briševac (1967.), pričuvni policajac PP Hrvatska Kostajnica. I on je nakon predaje na unskom mostu izdvojen od zarobljenika i otpremljen put okupirane hrvatske strane Une. ${ }^{76}$ - tijelo NN 183 je 1999. DNK metodom identificirano kao Drago Lenartić (1966.), PTT tehničar iz Zagreba. Kao pričuvni policajac PU Zagreb - PS Maksimir-Pešćenica u rujnu 1991. poslan je u obranu Hrvatske Kostajnice. Ranjen je i zarobljen 12. rujna 1991. na brdu Djed te je s drugim ranjenicima izdvojen iz zarobljeničke kolone. ${ }^{77}$

- tijelo NN 184 je 2005. DNK metodom identificirano kao Perica Levak-Ljubišić (1958.) iz kostajničkog sela Rosulje. Pričuvni policajac PP Hrvatska Kostajnica. Zarobljen je na brdu Djed 12. rujna 1991. te su ga lokalni Srbi izveli iz zarobljeničke kolone. ${ }^{78}$

- tijelo NN 185 je 2001. DNK metodom identificirano kao Damir Radić (1970.) iz Lokve-Rogoznice/Omiš. Pripadnik 1. brigade ZNG-a Tigrovi. Kao

ZSMKZG o pregledu i identifikaciji tijela NN 182. /Plavićevac. Br. Sp. 61.755-696/1997., od 16. V. 1997.; Zapisnik ZSMKZG o pregledu i identifikaciji tijela NN 183./Plavićevac. Br. Sp. 61.756-697/1997., od 16. V. 1997.; Zapisnik ZSMKZG o pregledu i identifikaciji tijela NN 184./Plavićevac. Br. Sp. 61.757-698/1997. od 16. V. 1997.; Zapisnik ZSMKZG o pregledu i identifikaciji tijela NN 185./Plavićevac. Br. Sp. 61.752-693/1997. od 16. V. 1997.; Zapisnik ZSMKZG o pregledu i identifikaciji tijela NN186./Plavićevac. Br. Sp. 61.758-699/1997. od 16. V. 1997.; Zapisnik ZSMKZG o pregledu i identifikaciji tijela NN 187./Plavićevac. Br. Sp. 61.747-688/1997. od 16. V. 1997.; Zapisnik ZSMKZG o pregledu i identifikaciji tijela NN 188./Plavićevac. Br. Sp. 61.753-694/1997., od 16. V. 1997.; Zapisnik ZSMKZG o pregledu i identifikaciji tijela NN 189./Plavićevac. Br. Sp. 61.750-691/1997., od 16. V. 1997.

74 AŽDOS. Spis KN-DO-28/04. Zapisnik ZSMKZG o identifikaciji tijela, od 20. III. 2009. i MBUZN-STOZNDR. PD Vukadin Stipica br. 2525.

75 AŽDOS. Spis KN-DO-28/04. Zapisnik ZSMKZG o identifikaciji tijela, od 18. V. 1999. i MBUZN-STOZNDR. PD Vujčić Dražen br. 631.

76 MB-UZN-STOZNDR. Zapisnik ZSMKZG o identifikaciji tijela, od 3. VI. 1997. i PD Briševac Davorin br. 168.

77 AŽDOS. Spis KN-DO-28/04. Zapisnik ZSMKZG o identifikaciji tijela, od 8. VI. 1999. i MBUZN-STOZNDR. PD Lenartić Drago br. 633.

78 AŽDOS. Spis KN-DO-28/04. Zapisnik ZSMKZG o identifikaciji tijela, od 8. VI. 2005. i MBUZN-STOZNDR. PD Levak Perica br. 1353. 
zapovjednik obrane, na brdu Djed zarobljen je 12. rujna 1991. i izdvojen iz zarobljeničke kolone. ${ }^{79}$

- tijelo NN 186 je 1997. identificirano kao Tomislav Jergović (1963.) iz sela Donji Kukuruzari. Civil. Nakon predaje na unskom mostu u Bosanskoj Kostajnici, u noći s 12. na 13. rujna, odvojen je od zarobljenika i otpremljen na okupiranu hrvatsku stranu Une. ${ }^{80}$

- tijelo NN 187 je 1999. DNK metodom identificirano kao Petar Galić (1945.), zidar iz Kostajničkog Selišta. Civil. Nakon predaje na unskom mostu nasilno je odveden na okupiranu hrvatsku stranu Une. ${ }^{81}$

- tijelo NN 188 je 2005. DNK metodom identificirano kao Vlado Andrijević (1945.), pričuvni policajac PP Hrvatska Kostajnica. Zarobljen je pri padu Hrvatske Kostajnice 12. rujna $1991 .^{82}$

- tijelo NN 189 je 1997. identificirano kao Željko Vujanović (1966.), radnik Elektre iz Hrvatske Kostajnice. Civil. Nasilno je odveden pri padu Hrvatske Kostajnice 12. rujna $1991 .^{83}$

Ova je grobnica po sastavu žrtava još heterogenija od one u Donjem Hrastovcu. U njoj su tijela dvojice zagrebačkih pričuvnih policajaca, četvorice kostajničkih policajaca, od toga jednog djelatnog i trojice pričuvnih, tijelo jednog pripadnika ZNG-a te posmrtni ostaci trojice kostajničkih civila. Sedam su žrtava osobe mlađe dobi, a tri srednje, dok ih je sedam neoženjeno. Sve su žrtve Hrvati, rimokatolici. Nijedna žrtva nije stradala u borbi, već su likvidirane nakon nasilnog odvođenja. Budući da su žrtve izdvojene iz većih skupina zarobljenika, može se pokušati analizirati motive za izdvajanje i likvidaciju. Dvojica zagrebačkih policajaca bila su ranjena, a time i potencijalna smetnja u transportu. Gardist Damir Radić likvidiran je jer je bio zapovjednik obrane jakog uporišta Djed. Ostale su žrtve domicilni Hrvati, kojih je, ukupno gledano, malo zarobljeno 12. rujna 1991. Većina kostajničkih Hrvata nije se predala, već je izvela proboj prema Hrvatskoj Dubici, tako da izdvajanje ove sedmorice zasigurno ima za motivaciju osobne osvete lokalnih Srba.

\footnotetext{
79 AŽDOS. Spis KN-DO-28/04. Zapisnik ZSMKZG o identifikaciji tijela, od 14. VI. 2001. i MBUZN-STOZNDR. PD Radić Damir br. 2766.

80 MB-UZN-STOZNDR. Zapisnik ZSMKZG o identifikaciji tijela od 3. VI. 1997. i PD Jergović Tomislav br. 1828.

81 MB-UZN-STOZNDR. Zapisnik ZSMKZG o identifikaciji tijela, od 14. IX. 1999. i PD Galić Petar br. 1231.

82 MB-UZN-STOZNDR. Zapisnik ZSMKZG o identifikaciji tijela od 10. II. 2005. i PD Andrijević Vlado br. 2526.

83 AŽDOS. Spis KN-DO-28/04. Zapisnik ZSMKZG o identifikaciji tijela NN 189., od 3. VI. 1997. i MB-UZN-STOZNDR. PD Vujanović Željko br. 650.
} 


\section{Višnjički bok/Cvetin vir}

Poslije pada Hrvatske Kostajnice srpski su se napadi usmjerili prema selima na istoku općine - Baćin, Hrvatska Dubica i Cerovljani. Nakon pada Baćina, 16. rujna 1991., sve je zatečeno stanovništvo „nestalo“. Većina, 16 osoba, nije nađena, a manji broj, 10 osoba, ekshumiran je iz više pojedinačnih grobova te iz masovne grobnice u šumi Višnjički bok, tj. u šumskom predjelu Cvetin vir, 5 kilometara od bivšeg sela Predore. ${ }^{84}$ Lokacija je već pri prvoj provedbi policijskog izvida bila uočljiva, budući da su na površini zemlje bili vidljivi ostaci kostiju. Ekshumaciju je 16. listopada 1996. provela 12-člana mješovita Radna grupa. ${ }^{85}$ Nađeni su posve skerletizirani ostaci. Prema tragovima nagorjelosti kostiju i ostacima odjeće, zaključeno je da su tijela na tom mjestu bila zapaljena. U jednoj je kosti nađeno puščano zrno manjeg kalibra ${ }^{86} \mathrm{Na}$ Zavodu za sudsku medicinu i kriminalistiku u Zagrebu utvrđeno je da su to ostaci sedam osoba, koje su dobile identifikacijske brojeve od NN 001 do NN 005 te dvije slovne oznake. Budući da su kosti bile ispremiješane, na Zavodu se tek po dužoj usporedbi uspjelo odrediti koje kosti čine koji kostur. ${ }^{87}$ Identifikacija, započeta 1996., još nije završena jer su dva tijela neidentificirana. Podaci o žrtvama:

- za tijelo NN 1 obdukcija je pokazala da pripada jačem muškarcu, starom 65 - 75 godina. Budući da je tijelo dugo bilo nepokopano, svi su mekani dijelovi propali, a na kostima je izrasla mahovina. Neke su kosti bile izložene vatri, pa su stoga pocrnjele. Velik je dio lubanje nedostajao, a dio koji je ostao sagorio je. ${ }^{88}$ Tijelo do danas nije identificirano.

- prvo od tijela identificirano je 1996. na Zavodu za sudsku medicinu i kriminalistiku u Zagrebu kao Ivo Pezo (1910.), poljoprivrednik iz Hrvatske Dubice.

84 APUSM. Izvješće PUSM-Odjel krim. policije o zločinima u Baćinu i Hrv. Dubici počinjenih tijekom rujna i listopada 1991. god. Br. 511-10-04/02-3620/11.SH., od 10. X. 2011. upućeno Udruzi Abeceda demokracije.

85 Iz Radne grupe za lociranje, ekshumaciju i identifikaciju civilnih i vojnih žrtava rata ušli su: pukovnik Mladen Pezelj - predstavnik MORH-a, natporučnik Marko Miloš - povjerenik Komisije za zatočene i nestale Vlade RH, dr. Drinko Baličević sa Zavoda za kliničku patologiju bolnice „Sestara milosrdnica“. Iz PUSM-a: Nikola Vidović, Adam Garvanović, Alojzije Đuračić, Elvir Šehić, Miljenko Bošnjak i Ramiz Hodžić. Iz PP H. Kostajnica Dražen Grgurić. Iz Županijskog suda Sisak: predsjednik Suda Josip Budinski i zapisničarka Ljerka Kolarić. Prisustvovali su promatrač EZ-a Jan Gallus i prevoditelj Luka Poreša.

86 MB-UZN-STOZNDR. Zapisnik Istražnog odjela Županijskog suda u Sisku od 16. X. 1996. KIR-773/96., KIR-774/96., KIR-775/96., KIR-776/96., KIR-777/96., KIR-788/96. u predmetu provođenja istražnih radnji ekshumacija posmrtnih ostataka civilnih i vojnih žrtava rata na području općine H. Kostajnica.

87 MB-UZN-STOZNDR. Zapisnik ZSMKZG o obdukciji posmrtnih ostataka lok. 2./Višnjićki Bok, od 16. X. 1996.

88 MB-UZN-STOZNDR. Fascikl Višnjićki Bok. Zapisnik ZSMKZG o identifikaciji ostataka kostiju s lokacije Višnjićki Bok, tijelo NN 1. Br. 60.824-1149/96., od 25. X. 1996. 
Civil. Nejasne su okolnosti pod kojima je tijelo dospjelo u ovu grobnicu jer je Ivo sa suprugom Sofijom 20. listopada 1991. bio zatvoren u Vatrogasnom domu u Hrvatskoj Dubici. ${ }^{89}$ No, tijelo Sofije Pezo ekshumirano je iz masovne grobnice u Baćinu, a Ivini posmrtni ostaci iz ove šumske grobnice. ${ }^{90}$

- tijelo NN 2 je 2003. identificirano kao Nikola Barunović (1933.) iz Baćina, radnik poduzeća Komunalije u Bosanskoj Dubici. Civil. ${ }^{91}$

- tijelo NN 3 je 2011. na osnovi DNK analize identificirano kao Antun Ćorić (1941.) iz Baćina, pripadnik pričuvnog sastava ZNG-a. ${ }^{92}$

- tijelo NN 5 je 2009. na osnovi DNK analize identificirano kao Vera Ćorić (1931.), domaćica iz Baćina. Civil.93

- tijelo s oznakama Viš. Bok-B. H. i Viš. Bok-B. F. je 2011. na osnovi DNK analize identificirano kao Katarina Lončar (1931.), domaćica iz Baćina. Civil. $^{94}$

Okolnosti su nastanka grobnice nejasne, a nije ih uspjela rasvijetliti ni opsežna policijska istraga. Poznate su žrtve iz ove grobnice, po svom statusu, spolu i mjestu boravka, vrlo raznolike. Jedna žrtva, srednje životne dobi, bila je pripadnik hrvatskih obrambenih struktura, no nema podataka da je sudjelovala u borbi ili stradala u njoj. Četiri su osobe civili i svi su starije životne dobi. Glede spola, četiri su muškog spola, dvije ženskog, a jedna nepoznata. Svih je pet poznatih žrtava hrvatske nacionalnosti, rimokatolici. Za četiri poznate osobe iz Baćina može se pretpostaviti da su istodobno likvidirane oko 16. rujna, kada su ,nestali“ svi stanovnici sela, dok je osoba iz Hrvatske Dubice vjerojatno naknadno ondje dovedena 21. listopada i likvidirana.

\section{Skelište/Baćin}

Nakon vukovarske Ovčare, najveća masovna grobnica nastala na mjestima skupnog ubojstva žrtava Domovinskog rata u Republici Hrvatskoj jest ona u Pounju, u selu Baćin. Idući cestom od Hrvatske Dubice prema Baćinu, neposredno prije prve

89 MB-UZN-STOZNDR. Fascikl Višnjićki Bok. Zapisnik ZSMKZG o identifikaciji tijela, od 6. XI. 1996. i PD Pezo Ivo br. 1059.

MB-UZN-STOZNDR. PD Pezo Sofija br. 1060.

MB-UZN-STOZNDR. Fascikl Višnjićki Bok. Zapisnik ZSMKZG o identifikaciji mrtvih tijela, od 1. VII. 2003. i PD Barunović Nikola br. 689.

MB-UZN-STOZNDR. PD Ćorić Antun br. 410. i Fascikl Višnjićki Bok. Rezultati analize DNA ZSMKZG o identifikaciji Antuna Ćorića, od 26. X. 2011.

MB-UZN-STOZNDR. Antemortalni podaci za nestalu osobu - Ćorić Vera, od 27. III. 2012. i Fascikl Višnjićki Bok. Rezultati analize DNA ZSMKZG o identifikaciji Vere Ćorić, od 17. VI. 2009.

94 MB-UZN-STOZNDR. PD Lončar Kata br. 897. i Fascikl Višnjićki Bok. Rezultati analize DNA ZSMKZG o identifikaciji Kate Lončar, od 26. X. 2011. 
seoske kuće, s lijeve je strane ceste zemljište širine 30 do 50 metara do rijeke Une, u naravi livada i obala rijeke, poznat kao Skelište jer je ondje nekad bio skelski prijelaz, koji je povezivao obale Une. Ondje je ekshumirano 56 tijela, uglavnom stanovnika Hrvatske Dubice i Cerovljana. U listopadu 1991. srpske su okupacijske vlasti sastavile popis preostalih Hrvata u Hrvatskoj Dubici i Cerovljanima, nakon čega im je zapovjeđeno da se 20. listopada 1991. okupe u vatrogasnim domovima u ovim dvama mjestima. Većina je poslušala, dok su neki privedeni na silu. Svi su zatočeni te su se držali pod oružanom stražom. Tijekom noći, s pomoću prijateljskih veza nekolicina je puštena, tako da je u domovima ostalo najmanje 56 osoba, sve redom civili, mahom starice i starci te bolesne osobe. Sutradan, 21. listopada 1991., svi su odvezeni u Baćin i iskrcani na Skelištu, gdje su ih pripadnici Milicije SAO Krajine poubijali iz automatskih pušaka. Tijela su ostavljena ležati nekoliko dana, nakon čega ih je 56 zakopano bagerom. ${ }^{95}$ Pretpostavlja se da su tada na Skelištu ubijena 74 civila i da je dio tijela bačen u Unu. ${ }^{96}$

Još za vrijeme okupacije, nakon zaprimanja podatka o odvođenju 60-ak osoba oko 20. listopada 1991. iz Hrvatske Dubice i Cerovljana, PU Sisak nastojala je doznati njihovu sudbinu. Primarni izvori bile su osobe koje su dolazile s okupiranog područja te obitelji i rodbina nestalih, koje su preko raznih „kanala“ dolazile do informacija. Tako se doznalo da su iz dubičkog Vatrogasnog doma odvedene prema zapadu. ${ }^{97}$ No, podaci o njihovoj daljnjoj sudbini bili su različiti. Izrađujući ovaj rad, pregledao sam sve anketne listove o tim nestalim osobama, koji se čuvaju u Ministarstvu branitelja - Upravi za zatočene i nestale - Sektoru za traženje osoba zatočenih i nestalih u Domovinskom ratu. U njima su podaci koje su o sudbini nestalih iz Hrvatske Dubice i Cerovljana dali članovi obitelji i rođaci u veljači i ožujku 1994., pri anketiranju koje su zajednički proveli Ured za žrtve rata, Hrvatski Crveni križ i Odjel za informiranje Ministarstva zdravstva. Prema tim listovima, većina je anketiranih odgovorila da ne zna ništa o sudbini nestalih osoba. ${ }^{98}$ Nekolicina je navela da su ubijeni, no da ne zna ništa više. ${ }^{99}$

95 APUSM. Izvješće PUSM-Odjel krim. policije o zločinima u Baćinu i Hrv. Dubici počinjenih tijekom rujna i listopada 1991. god. Br. 511-10-04/02-3620/11.SH., od 10. X. 2011. upućeno Udruzi Abeceda demokracije.

96 MB-UZN-STOZNDR. Dopis Tužiteljstva Međunarodnog suda Ujedinjenih naroda za bivšu Jugoslaviju Uredu za suradnju s Međunarodnim sudom Vlade Republike Hrvatska o slučaju Skelište/Baćin. Oznaka: INV/3183/t/GB/GM/JL-TO4/sf(70)., od 8. IV. 1998.

97 MB-UZN-STOZNDR. Zapisnik Istražnog odjela Županijskog suda Sisak od 4. IV. 1997. KIR200/1997. u predmetu provođenja istražne radnje ekshumacije i identifikacije posmrtnih ostataka civilnih žrtava rata na lokaciji Skelište/Baćina, obavljenih od 13. III. do 4. IV. 1997. U potpisu istražni sudac Josip Budinski.

98 MB-UZN-STOZNDR. PD Đukić Antun br. 111.; PD Krnić Mijo br. 293.; PD Šestić Marija br. 354.; PD Antolović Marija br. 1183.; PD Alavančić Terezija br. 1275.; PD Tepić Ana br. 1461.; PD Tepić Dušan br. 1462.; PD Đukić Marija br. 1839.

99 MB-UZN-STOZNDR. PD Mucavac Antun br. 490. i PD Blinja Katarina br. 956. 
Najviše je anketiranih odgovorilo da su odvedeni (navodno na razmjenu) u logor u Glini ${ }^{100}$, manje privatne logore oko Hrvatske Kostajnice ili Petrinje, na Šamarici, u Komogovini i Crkvenom boku. ${ }^{101}$ Neki su vjerovali da su još živi. Obitelj Katarine Blinje čak je tri puta u logor Glina slala obiteljske poruke u nadi da je ona ondje zatočena ${ }^{102}$, a obitelj Jukić iz Zagreba i u travnju 1995. preko Međunarodnog Crvenog križa pokušala je kontaktirati s Marijom Jukić iz Hrvatske Dubice. Iz službe traženja Crvenog krsta RSK odgovorili su im da je starica „otišla za Hrvatsku“. ${ }^{103}$

Neki su anketirani odgovorili da su nestali odvedeni u logor Glina, odakle su ih vratili u Hrvatsku Dubicu i pogubili. ${ }^{104}$ No, nekolicina je imala točnije spoznaje, navodeći da su odvedeni u Baćin i strijeljani. ${ }^{105}$ Pri određivanju točne mikrolokacije stratišta anketirani su uglavnom imali krive podatke, navodeći lokalitet Krečane. ${ }^{106}$ Samo je jedan anketirani - Vlado Pezo, sin ubijenih Ivana i Sofije Pezo - dajući podatke za traženje oca i majke, naveo točnu lokaciju grobišta - Skelu u Baćinu. ${ }^{107}$ Nije to jedini navod ove lokacije. U lipnju 1992. Dragoljub R., Srbin iz Bosanske Dubice, dao je opširan iskaz u PS Novska, o ratnim zbivanjima na području obiju Dubica. Govoreći o vođama pobune u Hrvatskoj Dubici, Mili Mišljenoviću i Stevi Dodošu, rekao je: Po padu Hrv. Dubice u istoj su izvršeni stravični zločini tako da je pobijeno oko 100 ljudi, a među kojima i nešto Srba zbog suradnjes MUP-om. U mjestu Krečane, ubijeno je oko 80 ljudi koji su pokopani kod Baćinske skele u bašči poštara Nikića ili Mikića iz Baćina. ${ }^{108}$ Ako se navedeno ima u vidu, jasno je da su nakon oslobođenja djelatnici PU sisačko-moslavačke imali dosta posla prije nego što se potvrdila točnost podataka da je grobnica smještena u Baćinu. ${ }^{109}$ No, nije se moglo pristupiti ekshumaciji jer se nalazila uz Unu, tik do granice s Republikom Srpskom, koja je tek u travnju 1996. demilitarizirana, nakon čega

$\overline{100}$ MB-UZN-STOZNDR. PD Antolović Josip br. 9.; PD Dikulić Ruža br. 484.; PD Dikulić Ana br. 892.; PD Dikulić Stjepan br. 893.; PD Đukić Marija br. 1839.

101 MB-UZN-STOZNDR. PD Vladić Kata br. 721.; PD Ferić Kata br. 738.; PD Ferić Anka br. 740.; PD Blinja Ana br. 743.; PD Blinja Nikola br. 745.; PD Ferić Juraj br. 746.; PD Blinja Josip br. 955.

102 MB-UZN-STOZNDR. PD Blinja Katarina br. 956.

103 MB-UZN-STOZNDR. PD Jukić Marija br. 2498.

104 MB-UZN-STOZNDR. PD Batinović Marija br. 626.

105 MB-UZN-STOZNDR. PD Švračić Antun br. 1766. i PD Švračić Marija br. 1768.

106 MB-UZN-STOZNDR. PD Piktija Anka br. 266.; PD Sabljar Stjepan br. 500.; PD Jukić Vera br. 953.; PD Jukić Filip br. 957.; PD Alavančić Terezija br. 1275.

107 MB-UZN-STOZNDR. PD Pezo Ivo br. 1059. i PD Pezo Sofija br. 1060.

108 Sl. zabilješka PS Novska o iskazu R. Dragoljub. Br. 511-06-31-819/92. I.F., od 8. VI. 1992.

109 MB-UZN-STOZNDR. Zapisnik Istražnog odjela Županijskog suda Sisak od 4. IV. 1997. KIR200/1997. u predmetu provođenja istražne radnje ekshumacije i identifikacije posmrtnih ostataka civilnih žrtava rata na lokaciji Skelište kod Baćina, obavljenih od 13. III. do 4. IV. 1997. 
je počelo smirivanje, uz povremene oružane incidente na granici. Na Skelištu se tek 19. veljače 1997. moglo izvesti probno iskapanje, pri čemu su nađene ljudske kosti i potvrđena lokacija grobnice. ${ }^{110}$

Nakon što je oformljena 17-člana mješovita Radna grupa ${ }^{111}$, 13. ožujka 1997. počeli su zemljani radovi, najprije bagerima, a potom ručno. Ekshumacija i identifikacija vršile su se kontinuirano do 4. travnja 1997. Nakon skidanja gornjeg sloja zemlje otkrivena je masovna grobnica, duga oko 60 i široka oko 15 metara. Unutar nje nađeno je šest mikrolokacija, koje su označene brojevima 1, 1A, 1B, 1C, 1D i 1E, u kojima je bilo nagomilano 56 ljudskih tijela u nekoliko skupina. Svako je tijelo nakon iskapanja dobilo identifikacijski broj u kontinuitetu od NN 102 do NN 134 te od NN 140 do NN 162. Usto je u taj identifikacijski broj svakom tijelu dodan i broj koji je pokazivao kojim je redoslijedom neko tijelo iskopano te slovo B, kao kratica lokacije Baćin (npr. NN 103/2B). ${ }^{112}$

Tijekom ekshumacije nijedno tijelo, tj. kostur nije nađen cjelovit. Sva su bila izlomljena, deformirana i raskomadana u više dijelova. Većina lubanja bila je polomljena u fragmente i odvojena od tijela, kao i ruke, noge, vilice... Obdukcija je pokazala da je nekim tijelima nedostajala većina kostiju. Tijela su usto bila „zgužvana“, savinuta u neprirodne položaje te međusobno isprepletena u jamama. Bila je to posljedica korištenja bagera pri zakopavanju leševa 1991. Žrtve su nađene odjevene u ostatke civilne, muške i ženske, odjeće i obuće s većom količinom osobnih predmeta: naočala, krunica, lijekova i medicinskih pomagala (zubne proteze, metalna pločica ugrađena u nogu, suspenzorij, proteza na kukovima, elastični pojas, drveni štap), češljeva, kišobrana, ručnih satova na kostima ruku, upaljača, ključeva, novčanika s jugoslavenskim i njemačkim novcem, zlatnog nakita (naušnice, ogrlice, prstenje). Uz tijela je nađen i veći broj osobnih dokumenata sljedećih stanovnika Hrvatske Dubice i Cerovljana: Josipa Blinje, Terezije

$\overline{110}$ MB-UZN-STOZNDR. Shema lokacije ekshumacije - probnog iskapanja u Baćinu od 19. II. 1997.

111 Iz Radne grupe za lociranje, ekshumaciju i identifikaciju civilnih i vojnih žrtava rata ušli su: pukovnik Ivan Grujić - predsjednik Komisije za zatočene i nestale Vlade RH, natporučnik Marko Miloš - povjerenik te Komisije i satnik Branko Bekavac - predstavnik MORH-a (Odjel za skrb), doc. dr. Davor Strinović, prof. dr. Josip Škavić, dr. Stjepan Gusić, dr. Josip Čadež i dr. Hrvoje Brkić sa ZSMKZG-a, dr. Drinko Baličević sa Zavoda za kliničku patologiju bolnice „Sestara milosrdnica“. Iz PUSM-a: Nikola Vidović, Elvir Šehić, Alojzije Đuračić i Ramiz Hodžić. Iz Županijskog suda Sisak: predsjednik Suda Josip Budinski i zapisničarka Ljerka Kolarić. Ekshumaciji je prisustvovao promatrač EZ-a Werner Zofal, uz prevoditeljicu Vedranu Aužinu, a naknadno i forenzičar John Gerns - predstavnik Međunarodnog suda iz Haaga, prevoditeljica Simona Vuletić, promatrač EZ-a Ioannis Fotoglou te prevoditelj Damir Balaban.

112 MB-UZN-STOZNDR. Zapisnik Istražnog odjela Županijskog suda u Sisku od 4. IV. 1997. KIR-200/1997. u predmetu provođenja istražne radnje ekshumacije i identifikacije posmrtnih ostataka civilnih žrtava rata na lokaciji Skelište kod Baćina, obavljenih od 13. III. do 4. IV. 1997. U potpisu istražni sudac Josip Budinski. 
Kramarić, Mije Čovića, Antuna Mucavca, Terezije Alavančić, Antuna Đukića, Stjepana Dikulića, Ane Dikulić, Sofije Pezo, Marije Jukić i Josipa Antolovića. Nađene su i veće količine ostataka kose, spletene u ženske pletenice i punđe. Na velikom broju odjeće bila su vidljiva brojna ovalna oštećenja, a na ostacima tijela strijelne rane, nastale od pogodaka metaka, dok su u odjeći nađena zrna metaka, a među tijelima nekoliko čahura metaka. Uz rub ceste, na četirima razmaknutim mjestima nađeno je 77 čahura puščanih metaka. Bilo je to mjesto odakle je djelovao streljački vod, koji je 1991. poubijao dubičko-cerovljanske žrtve. ${ }^{113}$ Sva su se ekshumirana tijela s nalazima predmeta sukcesivno otpremala u Zavod za sudsku medicinu i kriminalistiku u Zagrebu, gdje su se vršile obdukcije. Nakon toga tijela su vraćena u Baćin radi identifikacije. ${ }^{114}$

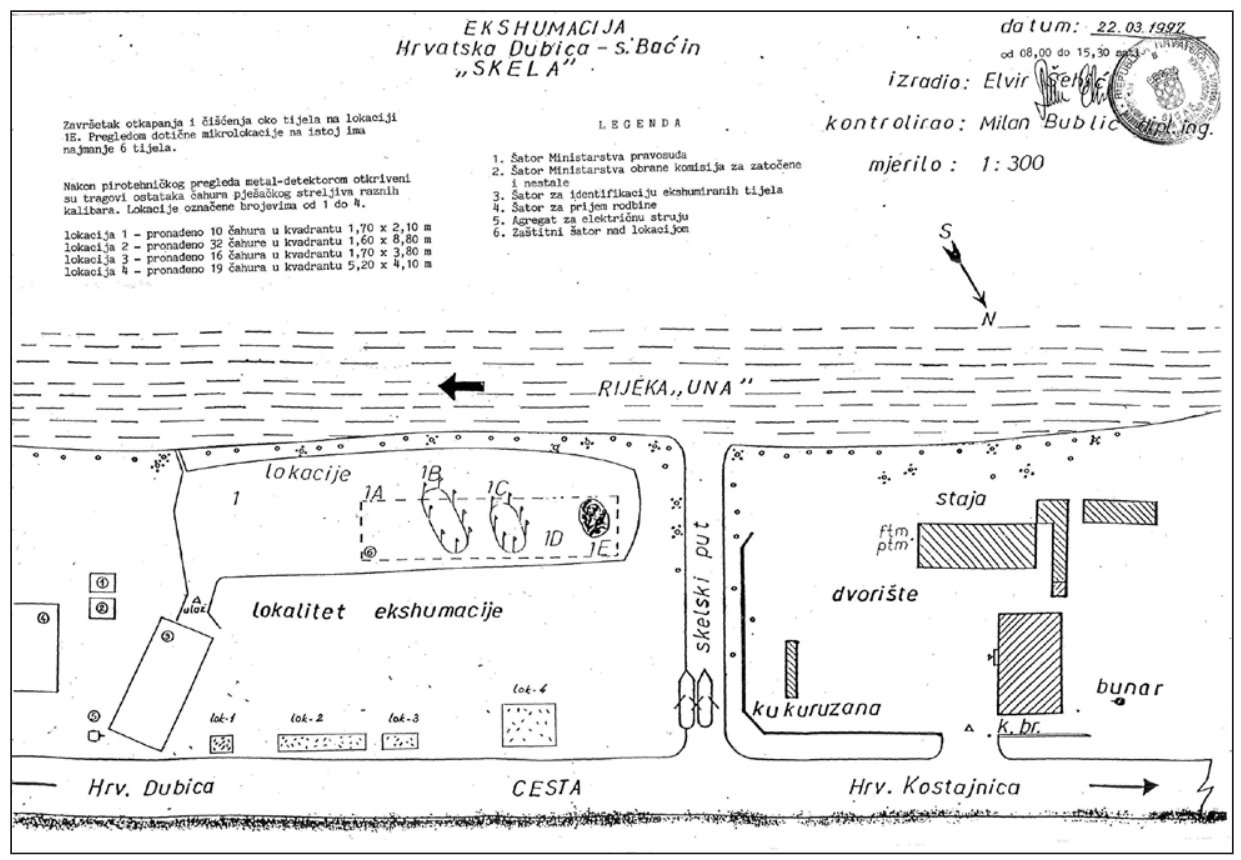

06 - Radni zemljovid Radne grupe za ekshumaciju masovne grobnice Skelište u Baćinu, s ucrtanim lokacijama jama s žrtvama i nalaza čahura streljačkog voda.

113 MB-UZN-STOZNDR. Zapisnik Istražnog odjela Županijskog suda Sisak od 4. IV. 1997. KIR200/1997. u predmetu provođenja istražne radnje ekshumacije i identifikacije posmrtnih ostataka civilnih žrtava rata na lokaciji Skelište/Baćin, od 13. III. do 4. IV. 1997.; Fotoelaborat PUSM ekshumacija od 13. 03./01. 04. 1997. na lokaciji Skela u Baćinu. Br. 511-10-04/06-68A-MG 173/97/98-1., od 18. II. 1998., s opisom slika; Dnevnik rada ekipe za ekshumacije na lokaciji H. Dubica - Skelište od 13. 03. do 10. 04. 97.

114 MB-UZN-STOZNDR. Svežanj 56 naredbi Istražnog odjela Županijskog suda u Sisku o ekshumaciji leševa radi njihova pregleda i obdukcije. KIR-ovi od 201/97. do 289/97. Naredbe izdane od 20. III. do 1. IV. 1997. 
Obdukcije su pokazale da je smrt kod svih žrtava bila uzrokovana višestrukim prostrijelnim ranama. ${ }^{15}$ Nakon okončanja ekshumacije, 3. i 4. travnja u Baćinu je započela identifikacija posmrtnih ostataka žrtava, koju su pripremili stručnjaci zagrebačkog Zavoda za sudsku medicinu i kriminalistiku. Na identifikaciju je pozvana rodbina žrtava, a predočeni su predmeti i fotografije predmeta te dijelovi odjeće nađeni kod žrtava. Na osnovi toga te uvida u identifikacijske protokole identificirano je 33 od 56 nađenih tijela. ${ }^{116}$ Bili su to:

- tijelo 102/1B Marija Antolović (1917.), domaćica iz Cerovljana. ${ }^{117}$

- tijelo 103/2B Andrija Likić (1908.), umirovljenica iz Cerovljana. ${ }^{118}$

- tijelo 106/5B Katarina Lončar (1906.), poljoprivrednica iz Cerovljana. ${ }^{119}$

- tijelo 107/6B Josip Blinja (1926.), poljoprivrednik iz Cerovljana. ${ }^{120}$

- tijelo 108/7B Ana Lončar (1923.), domaćica iz Cerovljana. ${ }^{121}$

- tijelo 110/9B Mara Ćorić (1939.), domaćica iz D. Cerovljana. ${ }^{122}$

- tijelo 111/10B Antun Švračić (1920.), poljoprivrednik iz Hrvatske Dubice.

Uz njega je na Skelištu likvidirana i supruga Marija. ${ }^{123}$

- tijelo 116/15B Terezija Kramarić (1922.), domaćica iz Hrvatske Dubice. ${ }^{124}$

- tijelo 117/16B Antun Krivajić (1931.) iz Hrvatske Dubice. ${ }^{125}$

- tijelo 119/18A Stjepan Sabljar (1912.), umirovljenik iz Hrvatske Dubice. ${ }^{126}$

- tijelo 121/20B Mijo Čović (1915.), poljoprivrednik iz Hrvatske Dubice. ${ }^{127}$

- tijelo 123/22B Kata Ferić (1925.), domaćica iz Hrvatske Dubice. Likvidirana sa suprugom Jurajem i šogoricom Ankom Ferić. ${ }^{128}$

$\overline{115}$ MB-UZN-STOZNDR. Zapisnici o identifikaciji posmrtnih ostataka ZSMKZG-a.

116 MB-UZN-STOZNDR. Zapisnik Istražnog odjela Županijskog suda u Sisku od 4. IV. 1997. KIR-200/1997. u predmetu provođenja istražne radnje ekshumacije i identifikacije posmrtnih ostataka civilnih žrtava rata na lokaciji Skelište kod Baćina, obavljenih od 13. III. do 4. IV. 1997.; Zapisnici obrade tijela klasičnom sudskom medicinskom metodom ZSMKZG-a i Zapisnici o identifikaciji posmrtnih ostataka ZSMKZG-a.

117 MB-UZN-STOZNDR. PD Antolović Marija br. 1183.

118 MB-UZN-STOZNDR. PD Likić Andrija br. 505.

119 MB-UZN-STOZNDR. PD Lončar Kata br. 1531.

120 MB-UZN-STOZNDR. PD Blinja Josip br. 955.

121 MB-UZN-STOZNDR. PD Lončar Ana br. 1530.

122 MB-UZN-STOZNDR. PD Ćorić Mara br. 1618.

123 MB-UZN-STOZNDR PD Švračić Antun br. 1766.

124 MB-UZN-STOZNDR. Zapisnik ZSMKZG obrade tijela Kramarić Terezija klasičnom sudskom medicinskom metodom. Sp. 61.538-480/97., od 25. III. 1997.

125 MB-UZN-STOZNDR. Zapisnik ZSMKZG obrade tijela Krivajić Antun klasičnom sudskom medicinskom metodom. Sp. 61.532-474/97., od 25. III. 1997.

126 MB-UZN-STOZNDR. PD Sabljar Stjepan br. 500.

127 MB-UZN-STOZNDR. PD Čović Mijo.

128 MB-UZN-STOZNDR. PD Ferić Kata br. 738. 
- tijelo 125/24B Juraj Ferić (1923.), umirovljenik iz Hrvatske Dubice. Likvidiran je sa suprugom Katom i sestrom Ankom Ferić. ${ }^{129}$

- tijelo 126/25B Antun Mucavac (1946.) iz Hrvatske Dubice. Radnik u poduzeću Šipad - Kozara u Bosanskoj Dubici. ${ }^{130}$

- tijelo 128/27B Ana Tepić (1925.), domaćica iz Hrvatske Dubice. Jedina od identificiranih žrtava srpske nacionalnosti, pravoslavne vjere. S njom je na likvidaciju odveden i suprug Dušan, također Srbin. No, njegovo tijelo do danas nije identificirano. ${ }^{131}$

- tijelo 130/29B Marija Đukić (1923.), poljoprivrednica iz Hrvatske Dubice. ${ }^{132}$

- tijelo 131/30B Soka Volarević (1915.), poljoprivrednica iz Hrvatske Dubice. ${ }^{133}$

- tijelo 132/31B Marija Milašinović (1913.), domaćica iz Hrvatske Dubice. ${ }^{134}$ - tijelo 134/33B Terezija Alavančić (1925.), domaćica iz Hrvatske Dubice. ${ }^{135}$ - tijelo 140/34B Marija Švračić (1924.), domaćica iz Hrvatske Dubice. S njom je na Skelištu likvidiran i suprug Antun. ${ }^{136}$

- tijelo 141/35B Katarina Vladić (1931.), domaćica iz Hrvatske Dubice. ${ }^{137}$

- tijelo 142/36B Marija Batinović (1901.), domaćica iz Hrvatske Dubice. ${ }^{138}$

- tijelo 144/38B Barbara Kropf (1928.), domaćica iz Hrvatske Dubice. Likvidirana je sa suprugom Pavlom. ${ }^{139}$

- tijelo 145/39B Nikola Lončarić (1910.) iz Hrvatske Dubice. ${ }^{140}$

- tijelo 146/40B Anka Piktija (1920.), domaćica iz Hrvatske Dubice. ${ }^{141}$

- tijelo 147/41B Pavao Kropf (1931.) iz Hrvatske Dubice. S njime je likvidirana i supruga Barbara. ${ }^{142}$

- tijelo 148/42B Mijo Krnić (1929.), poljoprivrednik iz Hrvatske Dubice. ${ }^{143}$

$\overline{129}$ MB-UZN-STOZNDR. PD Ferić Juraj br. 746.

130 MB-UZN-STOZNDR. PD Mucavac Antun br. 490.

131 MB-UZN-STOZNDR. PD Tepić Ana br. 1461.

132 MB-UZN-STOZNDR. PD Đukić Marija br. 1839.

133 MB-UZN-STOZNDR. PD Volarević Soka br. 438.

134 MB-UZN-STOZNDR. Zapisnik ZSMKZG obrade tijela Milašinović Marija klasičnom sudskom medicinskom metodom. Sp. 61.560-502/1997., od 25. III. 1997.

135 MB-UZN-STOZNDR. PD Alavančić Terezija br. 1275.

136 MB-UZN-STOZNDR. PD Švračić Marija br. 1768.

137 MB-UZN-STOZNDR. PD Vladić Kata br. 721.

138 MB-UZN-STOZNDR. PD Batinović Marija br. 626.

139 MB-UZN-STOZNDR. PD Kropf Barbara.

140 MB-UZN-STOZNDR. PD Lončarić Nikola.

141 MB-UZN-STOZNDR. PD Piktija Anka br. 266.

142 MB-UZN-STOZNDR. PD Kropf Pavle.

143 MB-UZN-STOZNDR. PD Krnić Mijo br. 293. 
- tijelo 149/43B Antun Đukić (1933.), umirovljenik iz Hrvatske Dubice. ${ }^{144}$ - tijelo 152/46B Ana Dikulić (1942.), domaćica iz Hrvatske Dubice. Njen suprug Stjepan Dikulić s njom je odveden u Baćin; pri ekshumaciji pronađena je njegova osobna iskaznica, ali tijelo mu do danas nije identificirano. ${ }^{145}$

- tijelo 153/47B Veronika Stanković (1915.), umirovljenica iz Hrvatske Dubice. ${ }^{146}$

- tijelo 154/48B Sofija Pezo (1922.), poljoprivrednica iz Hrvatske Dubice. S njom je u Vatrogasni dom odveden i suprug Ivo, čije je tijelo ekshumirano iz masovne grobnice Cvetin vir. Nisu jasne okolnosti pod kojima se to dogodilo. ${ }^{147}$

- tijelo 157/51B Marija Jukić (1924.), domaćica iz Hrvatske Dubice. ${ }^{148}$

- tijelo 161/55B Josip Antolović (1910.), umirovljenik iz Hrvatske Dubice. ${ }^{149}$

Naknadno su na Zavodu za sudsku medicinu i kriminalistiku u Zagrebu 1997. identificirane još tri osobe:

- tijelo 127/26B Veronika Jukić (1919.), poljoprivrednica iz Hrvatske Dubice. ${ }^{150}$

- tijelo 118/17B Filip Jukić (1949.) iz Hrvatske Dubice. Radnik Komunalnog poduzeća u Bosanskoj Dubici. ${ }^{151}$

- tijelo 133/32B Anka Ferić (1926.), domaćica iz Hrvatske Dubice. S njom su na Skelištu likvidirani brat Juraj i šogorica Kata Ferić. ${ }^{152}$

Tijekom idućih godina utvrđen je identitet ovih tijela/osoba:

- tijelo 124/23B je 1999. identificirano kao Katarina Alavančić (1910.) iz Hrvatske Dubice. ${ }^{153}$

$\overline{144}$ MB-UZN-STOZNDR. PD Đukić Antun br. 111.

145 MB-UZN-STOZNDR. PD Dikulić Ana br. 892.

146 MB-UZN-STOZNDR. PD Stanković Veronika br. 1502.

147 MB-UZN-STOZNDR. PD Pezo Sofija br. 1060.

148 MB-UZN-STOZNDR. PD Jukić Marija br. 2498.

149 MB-UZN-STOZNDR. PD Antolović Josip br. 9.

150 MB-UZN-STOZNDR. Zapisnik ZSMKZG o identifikaciji posmrtnih ostataka Jukić Vere. Sp. 61.534-476/97., od 26. III. 1997.; Sl. bilješka Županijskog suda u Sisku od 1. V. 1997. KIR200/1997. o identifikaciji tri osobe s lokacije Skelište Baćin na ZSMKZG i PD Jukić Vera br. 953.

151 MB-UZN-STOZNDR. Zapisnik ZSMKZG o obdukciji posmrtnih ostataka Filipa Jukića. Sp. 61.553-495/97., od 27. III. 1997.; S1. bilješka Županijskog suda u Sisku od 1. V. 1997. KIR200/1997. o identifikaciji tri osobe s lokacije Skelište Baćin na ZSMKZG i PD Jukić Filip br. 957.

152 MB-UZN-STOZNDR. Zapisnik ZSMKZG o identifikaciji posmrtnih ostataka Ferić Anke. Sp. 61.533-475/97., od 26. III. 1997.; S1. bilješka Županijskog suda Sisak od 1. V. 1997. KIR200/1997. o identifikaciji tri osobe s lokacije Skelište Baćin na ZSMKZG i PD Ferić Anka br. 740.

153 MB-UZN-STOZNDR. PD Alavančić Katarina. 
- tijelo 109/8B je 2000. identificirano kao Ivan Kulišić (1926.), umirovljenik iz Hrvatske Dubice. ${ }^{154}$

- tijelo 105/4B je 2002. DNK metodom identificirano kao Katarina Blinja (1933.), poljoprivrednica iz Cerovljana. ${ }^{155}$

- tijelo 143/37B je 2003. DNK metodom identificirano kao Ruža Dikulić (1913.) iz Hrvatske Dubice. Njena kći Sofija Dikulić također je ekshumirana na Skelištu. ${ }^{156}$

- tijelo 150/44B je 2003. DNK analizom identificirano kao Marija Šestić (1922.), domaćica iz Hrvatske Dubice. ${ }^{157}$

- tijelo 159/53B je 2003. identificirano kao Sofija Dikulić (1946.) iz Hrvatske

Dubice. Pogubljena je sa svojom majkom Ružom Dikulić. ${ }^{158}$

- tijelo 160/54B je 2003. DNK metodom identificirano kao Ana Blinja (1923.), poljoprivrednica iz Cerovljana. S njom odveden i suprug Nikola, čije tijelo do danas nije identificirano, rođak Josip Blinja i sestra Katarina Blinja. ${ }^{159}$

- tijelo 122/21B je 2010. DNK metodom identificirano kao Ivan Trninić (1913.), umirovljenik iz Hrvatske Dubice. ${ }^{160}$

- tijelo 114/13B je 2010. DNK metodom identificirano kao Milka Čevizović (1931.), domaćica iz Uštice/Jasenovac, koja se zatekla u okupiranoj Hrvatskoj Dubici. ${ }^{161}$

Ukupno je do rujna 2015. identificirano 45 tijela iz grobnice u Baćinu. Uslijed objektivnih, tehničkih razloga identifikacija preostalih 11 ekshumiranih tijela/ osoba sa Skelišta do danas nije okončana. Prema evidenciji, radi se o: 1. tijelu muškarca starog oko 40 godina s evidencijskim brojem 104/3B ${ }^{162}$, 2. tijelu krupnije žene stare 60-ak godina s evidencijskim brojem 112/11B, kojoj je uzet uzorak, no dobiven genotip nije bio zadovoljavajućeg rezultata ${ }^{163}, 3$. tijelu krupnijeg muškarca starosti 40 - 50 godina s evidencijskim brojem $113 / 12 \mathrm{~B}^{164}, 4$.

154 MB-UZN-STOZNDR. PD Kulišić Ivan br. 98.

MB-UZN-STOZNDR. PD Blinja Katarina br. 956.

156 MB-UZN-STOZNDR. PD Dikulić Ruža br. 484.

157 MB-UZN-STOZNDR. Zapisnik ZSMKZG o identifikaciji tijela od 29. I. 2003. i PD Šestić Marija br. 354.

158 MB-UZN-STOZNDR. PD Dikulić Sofija br. 485.

159 MB-UZN-STOZNDR. PD Blinja Ana br. 743.

160 MB-UZN-STOZNDR. PD Trninić Ivan br. 934.

161 MB-UZN-STOZNDR. PD Čevizović Milka br. 690.

162 MB-UZN-STOZNDR. Zapisnici ZSMKZG o identifikaciji posmrtnih ostataka br. 104/3B. Sp. 61.530-472/97., od 25. III. 1997.

163 MB-UZN-STOZNDR. Zapisnici ZSMKZG o identifikaciji posmrtnih ostataka br. 112/11B. Sp. 61.547-489/1997., od 27. III. 1997. i Izvješće KBC Split - laboratorij za kliničku i sudsku genetiku od 15. III. 2010.

164 MB-UZN-STOZNDR. Zapisnici ZSMKZG o identifikaciji posmrtnih ostataka br. 113/12B. Sp. 61.529-471/97., od 25. III. 1997. 
tijelu starije žene s evidencijskim brojem $115 / 14 \mathrm{~B}^{165}$, 5. tijelu muškarca starosti 55 - 60 godina s evidencijskim brojem $120 / 19 \mathrm{~B}^{166}$, 6. tijelu žene starosti $50-60$ godina s evidencijskim brojem 129/28B ${ }^{167}$, 7. tijelu muškarca starosti 60 i više godina s evidencijskim brojem $151 / 45 \mathrm{~B}^{168}$, 8. glavi muškarca starosti preko 45 godina s evidencijskim brojem $155 / 49 \mathrm{~B}^{169}, 9$. posve razbijenoj glavi, vjerojatno ženskoj, evidencijskog broja $156 / 50 \mathrm{~B}^{170}, \mathbf{1 0}$. tijelu snažnijeg muškarca starog 55 - 70 godina s evidencijskim brojem $158 / 52 \mathrm{~B}^{171}$ i 11. ostaci glave muškarca starog preko 50 godina s evidencijskim brojem 162/56B. ${ }^{172}$ Valja napomenuti da su pri ekshumaciji nađeni dijelovi kostiju, koji nisu vezani ni uz jednu osobu ${ }^{173}$, kao i odjeća i obuća, koja nije vezana ni uz jedno tijelo ${ }^{174}$, iz čega se može zaključiti da je ondje smrtno stradalo više osoba od evidentiranih 56.

Prema sastavu identificiranih žrtava, ova masovna grobnica spada među homogenije. Sve su žrtve civili, stanovnici Hrvatske Dubice i Cerovljana, dok je jedna osoba iz sela Uštica. Svi su istodobno likvidirani na istome mjestu, daleko od linije bojišta i nevezano za bilo kakvo borbeno djelovanje. Od 45 identificiranih osoba, tri su bile srednje, a sve ostale starije životne dobi. Prema spolu, 29 su žrtava žene, a 16 muškarci. Jedna je osoba srpske nacionalnosti, pravoslavne vjere, a ostale su 44 Hrvati, rimokatoličke vjeroispovijedi. Glede bračnog stanja, 24 su osobe bile u braku, a ostale su uglavnom udovice i udovci. Većina je imala djecu. Uvidom u osobne dosjee žrtava uočio sam da je većina žrtava bila dosta lošeg zdravstvenog stanja; dio ih je bio kronično bolestan (srčane, plućne i bubrežne tegobe, visok tlak, astma), neki su bolovali od epilepsije i karcinoma,

$\overline{165}$ MB-UZN-STOZNDR. Zapisnik ZSMKZG o identifikaciji posmrtnih ostataka br. 115/14B. Sp. 61.539-481/97., od 25. III. 1997.

166 MB-UZN-STOZNDR. Zapisnik ZSMKZG o identifikaciji posmrtnih ostataka br. 120/19B. Sp. 61.546-488/97., od 27. III. 1997.

167 MB-UZN-STOZNDR. Zapisnik ZSMKZG o identifikaciji posmrtnih ostataka br. 129/28B. Sp. 61.535-477/97., od 26. III. 1997.

168 MB-UZN-STOZNDR. Zapisnik ZSMKZG o identifikaciji posmrtnih ostataka br. 151/45B., od 1. IV. 1997.

169 MB-UZN-STOZNDR. Zapisnik ZSMKZG o identifikaciji posmrtnih ostataka br. 155/49B., od 2. IV. 1997.

170 MB-UZN-STOZNDR. Zapisnik ZSMKZG o identifikaciji posmrtnih ostataka br. 156/50B., od 2. IV. 1997.

171 MB-UZN-STOZNDR. Zapisnik ZSMKZG o identifikaciji posmrtnih ostataka br. 158/52B., od 2. IV. 1997.

172 MB-UZN-STOZNDR. Zapisnici ZSMKZG o identifikaciji posmrtnih ostataka br. 162/56B., od 2. IV. 1997.

173 MB-UZN-STOZNDR. Zapisnici ZSMKZG o identifikaciji posmrtnih ostataka br. 163/57B., od 2. IV. 1997.

174 MB-UZN-STOZNDR. Zapisnici ZSMKZG o nalazu ženske zdjelice s natkoljenicom i ostacima odjeće i obuće - vreća bez broja XYZ. Br. Sp. 61.713-654/1997., od 13. V. 1997. 
a dosta ih je bilo invalidno i teško pokretno (reuma, umjetni kukovi, oštećene i ukočene noge te kralježnica). Ako se uzme u obzir i poznaje životna dob, onda je posve jasno da ovi ljudi nisu ni na koji način predstavljali opasnost za srpsku okupacijsku vlast na dubičkom području i da je jedini razlog za likvidaciju bila njihova etnička pripadnost.

\section{Gradsko groblje sv. Ane/Hrvatska Kostajnica}

Jedina masovna grobnica u Pounju, za koju bi se uvjetno moglo navesti da je nastala asanacijom terena, jest ona kod kostajničkoga gradskoga groblja sv. Ane. U njoj je pokopano pet osoba, stradalih na različitim mjestima u različitim okolnostima, u dužem periodu. U njoj su ukopi počeli krajem listopada 1991. i završili u siječnju 1993. Grobnica se nalazi na rubu groblja, uz cestu prema Hrvatskoj Dubici, u kanalu iza trafostanice, u koji su se bacala tijela i zatrpavala smećem i zemljom. Ova je grobnica prva ekshumirana u Pounju, 23. travnja 1996., kada je iz nje izvađeno pet žrtava. Najprije se bagerom skinuo sloj zemlje, dok se nije došlo do kostiju i ostataka odjeće, a na drugim dvama mjestima u istom se kanalu našlo ostatke mrtvačkih sanduka, u kojima su neka tijela bila bačena u kanal. Tijela su otpremljena u Zavod za sudsku medicinu i kriminalistiku u Zagrebu. ${ }^{175}$ Utvrđeno je da su u pitanju dvije žene i trojica muškaraca različite dobi. Za četvero je utvrđeno da su odjeveni u ostatke civilne odjeće i vunene deke te da imaju teška oštećenja lubanja, vjerojatno uzrokovana vatrenim oružjem. Peto, muško tijelo, odjeveno je u ostatke zelene vojničke odore, bez tragova ozljeda. Tijela su dobila identifikacijske oznake od NN 001 do NN 005. ${ }^{176}$ Budući da nije bilo indicija o identitetu, dugo ih se nije moglo identificirati. S ciljem njihova prepoznavanja, kao i drugih još neidentificiranih tijela, Komisija Vlade RH za zatočene i nestale u ožujku 1998. u Hrvatskoj Kostajnici organizirala je izlaganje fotografija tijela i uz njih nađenih predmeta. ${ }^{177}$

- na osnovi izloženih fotografija tijela NN 01 Ljubica Janković prepoznala je posmrtne ostatke svoga sina, Predraga Jankovića (1968.) iz Hrvatske Ko-

$\overline{175}$ MB-UZN-STOZNDR. Zapisnik Istražnog odjela Županijskog suda Sisak od 24. IV. 1997. u predmetu provođenja istražnih radnji ekshumacije posmrtnih ostataka civilnih i vojnih žrtava rata u mjestu G. Jame, Šatornja i H. Kostajnica provedenima 23. travnja 1997.

176 MB-UZN-STOZNDR. Zapisnik ZSMKZG o identifikaciji tijela NN 001. iz H. Kostajnice, lok. 1. groblje Sv. Ane. Sp. 60.154-478/96., od 7. V. 1996.; Zapisnik ZSMKZG o identifikaciji tijela NN 003. lok. 1. groblje Sv. Ane. Sp. 60.156-480/96., od 7. V. 1996.; Zapisnik ZSMKZG o identifikaciji tijela NN 002. lok. 1. groblje Sv. Ane. Sp. 60.155-479/96., od 7. V. 1996.; Zapisnik ZSMKZG o identifikaciji tijela NN 004. lok. 1. groblje Sv. Ane. Sp. 60.157-481/96., od 7. V. 1996.; Zapisnik ZSMKZG o identifikaciji tijela NN 005. lok. 1. groblje Sv. Ane. Sp. 60.158482/96., od 7. V. 1996.

177 MB-UZN-STOZNDR. Dopis Komisije Vlade RH za zatočene i nestale o identifikaciji posmrtnih ostataka branitelja Predraga Jankovića. Ur. br. 50412-99-4774/01., od 10. IX. 1999. 
stajnice. ${ }^{178}$ Naknadno, 2001. DNK metodom potvrđen je identitet. Janković je kao pripadnik 1. satnije Domobranske bojne Hrvatska Kostajnica HV-a zarobljen na straži u Sunji 16. siječnja 1993. sa suborcem Nikolom Kolarom. Janković je u Hrvatsku Kostajnicu dovezen mrtav, a Kolar je ranjen. Prema podacima dobivenima od predstavnika mirovnih snaga Ujedinjenih naroda, Predrag je poginuo kod pruge u selu Drljače. ${ }^{179}$

- tijelo NN 002 je 2003. identificirano kao Ivan Bučan (1947.) iz Umaga, vozač kamiona u tvrtki Istra-Auto. Civil. Pri povratku sa službenog puta iz Zavidovića (BiH), 25. ožujka 1992., nedaleko od hrvatske granice, kamion u kojem je bio sa suvozačem otele su tri naoružane osobe. Nakon što su ih opljačkali, uz zlostavljanje su ih potjerali u šumu kod Bosanske Kostajnice i ondje pucali na njih. Suvozač, Dario Doc, ranjen je, ali je uspio pobjeći, dok je Bučan ubijen. ${ }^{180}$

- tijelo NN 003 je 2004. na osnovi DNK metode identificirano kao Milan Jergović (1932.), umirovljenik iz D. Kukuruzara. Civil. Dana 26. listopada 1991. ubijen je u dvorištu vlastite kuće, sa suprugom Marijom i majkom Milkom. ${ }^{181}$

- tijelo NN 004 je 2004. na osnovi DNK metode identificirano kao Milka Jergović (1910.), domaćica iz D. Kukuruzara. Civil. Dana 26. listopada 1991. ubijena je u dvorištu vlastite kuće, sa sinom Milanom i snahom Marijom. ${ }^{182}$ - tijelo NN 005 je 2004. na osnovi DNK metode identificirano kao Marija Jergović (1944.), domaćica iz D. Kukuruzara. Civil. Dana 26. listopada 1991. ubijena je u dvorištu vlastite kuće, sa suprugom Milanom i svekrvom Milkom. ${ }^{183}$

Ako se promotre okolnosti stradanja žrtava i dugo razdoblje u kojem su stradale, ova masovna grobnica prije bi se mogla okarakterizirati kao „,sabiralište“ tijela ljudi „,nepoćudne“ nacionalnosti, koji nisu bili vrijedni ni klasičnog ukopa u zemlju, već ih se bacalo u jarak s grobljanskim smećem, nego kao asanacijska grobnica. To potvrđuje i podatak što su nedaleko od jarka, na dvjema lokacijama,

178 Isto.

179 MB-UZN-STOZNDR. Zapisnik ZSMKZG o identifikaciji tijela od 27. IV. 2001. i PD Janković Predrag br. 344. AŽDOS. Spis KN-DO-28/04.; S1. zabilješka PUSM o razgovoru s Mihajlom R. Br. 511-10-04/04-01., od 31. I. 2001.

180 MB-UZN-STOZNDR. Zapisnik ZSMKZG o identifikaciji tijela od 29. I. 2003. i PD Bučan Ivan br. 1331.

181 MB-UZN-STOZNDR. Izvješće KB Split-Odjel za patologiju i sudsku medicinu; Laboratorij za kliničku i sudsku genetiku o rezultatu analize uzoraka kostiju groblje Sv. Ane, od 8. VI. 2004. i PD Jergović Milan.

182 MB-UZN-STOZNDR. Isto i PD Jergović Milka.

183 MB-UZN-STOZNDR. Isto i PD Jergović Marija. 
nađena još tri tijela nepoznatih osoba, koja se u evidenciji Ministarstva branitelja vode zasebno, kao žrtve iz dvaju pojedinačnih grobova. ${ }^{184}$

Ova je grobnica po sastavu žrtava najheterogenija u Pounju. U njoj je tijelo jednog hrvatskog vojnika, troje kostajničkih i jednog istarskog civila. Tri su žrtve starije, jedna srednje i jedna mlađe dobi. Dvije su žrtve žene, a tri muškarci. Tri su bile u braku, jedna udovica, s tim da su svi imali djecu, i jedna neoženjena. Sve su žrtve Hrvati. Četiri su planski likvidirane, dok za petu postoji mogućnost da je poginula u borbi.

\section{Kostrići}

Selo Kostrići, smješteno u brdima sjeverno od Hrvatske Kostajnice, 15. studenog 1991. postalo je poprište jednog od najgorih zločina u Domovinskom ratu. Srpski su pobunjenici zauzeli selo bez otpora još u rujnu 1991., a toga su dana pripadnici Jedinice za posebne namjene MUP-a SAO Krajine „Kaline“ iz baze u Komogovinama, pod zapovjedništvom Stevana Borojevića „Gadafija“, bez poznatog razloga ušli u selo i pobili sve stanovnike koje su zatekli, njih ukupno 15, uključujući dvoje djece od dviju i četiriju godina, opljačkali kuće te potom spalili selo. Nakon nekoliko dana su ubili i šesnaestog stanovnika, koji se dan ranije nije zatekao u selu. ${ }^{185}$

184 Ekipa za ekshumaciju 15. listopada 1996., uz trafostanicu kod groblja sv. Ane, iskapala je lokaciju s desne strane ceste prema H. Dubici, s lijeve strane trafostanice, gledajući s ceste u pravcu prema groblju. Ekshumirano je žensko tijelo, označeno br. NN 001, lokacija br. 1., groblje sv. Ane, i otpremljeno u ZSMKZG radi identifikacije. Tijelo do danas nije identificirano. Pretpostavlja se da je riječ o Milki Galić (1921.) iz Kostajničkog Selišta, koja je, prema kazivanju svjedoka, za vrijeme okupacije umrla prirodnom smrću u svojoj kući. Susjeda Kata Govorčinović pokojnicu je odjenula za pokop te ju je odvezao „Komunalac“. MB-UZN-STOZNDR. Zapisnik Istražnog odjela Županijskog suda u Sisku od 15. X. 1996. KIR-765/96. u predmetu provođenja istražnih radnji ekshumacija posmrtnih ostataka civilnih i vojnih žrtava rata na području općine H. Kostajnica. i PD Galić Milka. Treća ekshumacija na groblju sv. Ane izvršena je 21. svibnja 1997., ispred ulaza u kapelicu. Nađena su dva tijela, koja su dobila brojeve NN 206 i NN 207 te su otpremljena u ZSMKZG, gdje je obdukcijom utvrđeno da je NN 206 tijelo muškarca starog između 22 i 26 godina, čiji je uzrok smrti bio udar minobacačke granate, tj. gelera po donjem dijelu tijela. Za tijelo NN 207 utvrđeno je da je riječ o muškarcu starom 35 - 40 godina, čiji su uzrok smrti bile strijelne rane glave i lijeve strane tijela. Do danas nijedno tijelo nije identificirano. MB-UZN-STOZNDR. Zapisnik Istražnog odjela Županijskog suda Sisak od 21. V. 1997. u predmetu provođenja istražnih radnji ekshumacija posmrtnih ostataka civilnih i drugih žrtava rata na području H. Kostajnice i H. Dubice.

185 Likvidirani su: 1. Bašić Mije Petar (1898.), 2. Bašić Franje Marija (1907.), 3. Bašić Vilka Petar (1940.), 4. Bašić Franje Jelka (1942.), 5. Bunjevac Mate Kata (1905.), 6. Jurić Josipa Milka (1929.), 7. Jurić Antuna Zlatko (1956.), 8. Jurić Jure Vera (1968.), 9. Jurić Zlatka Dario (1986.), 10. Jurić Zlatka Tomislav (1989.), 11. Jurić Josipa Marija (1930.), 12. Kostrić Petra Marija (1924.), 13. Kozić Mate Jure (1931.), 14. Kozić Ive Anka (1939.), 15. Krizman Filipa Ferdinand (1925.), 16. Krizman Petra Marija (1929.). PANDŽA-ORKAN (ur.). 2012: 38-49. 


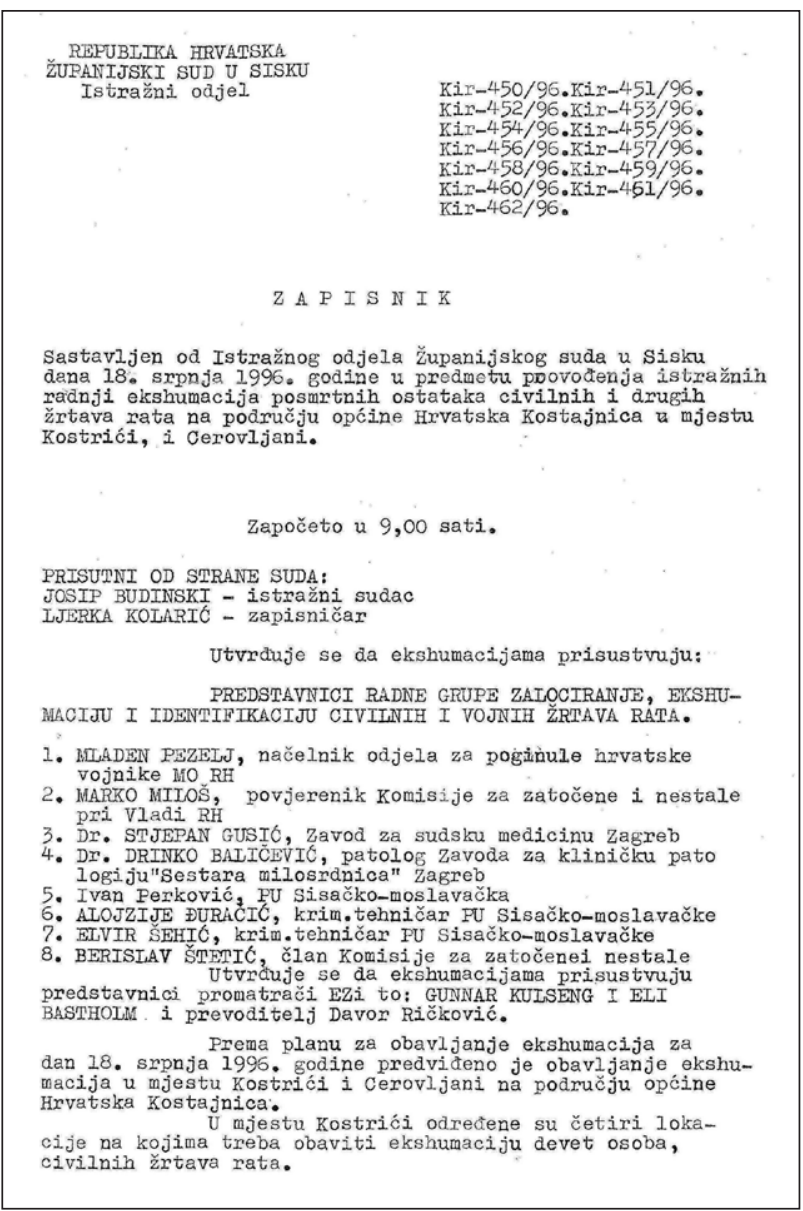

07 - Zapisnik o prvoj ekshumaciji žrtava u selu Kostrići 1996. godine.

Sudbina stanovnika Kostrića, zahvaljujući mještanima susjednih sela, okvirno se znala. Stoga je 18. srpnja 1996. Radna grupa za lociranje, ekshumaciju i identifikaciju civilnih i vojnih žrtava rata ${ }^{186}$ ondje izvršila ekshumacijske radnje na četirima mjestima u selu, gdje se očekivalo da će se naći posmrtni ostaci devetero osoba. Međutim, na lokaciji 1. (gdje se očekivao pronalazak Ferdinanda i Mare Krizman) nije nađeno ništa. Na lokaciji 2. nađeno je jedno žensko tijelo s teškim

$\overline{186}$ Iz Radne grupe za lociranje, ekshumaciju i identifikaciju civilnih i vojnih žrtava rata ušli su: Mladen Pezelj - načelnik Odjela za poginule hrvatske vojnike MORH-a, Marko Miloš-povjerenik Komisije za zatočene i nestale Vlade RH, dr. Stjepan Gusić sa ZSMKZG-a, dr. Drinko Baličević - patolog Zavoda za kliničku patologiju „Sestara milosrdnica“ Zagreb i Berislav Štetić - član Komisije za zatočene i nestale. Iz PUSM-a: Ivan Perković te kriminalistički tehničari Alojzije Đuračić i Elvir Šehić. Prisustvovali su promatrači EZ-a, Gunnar Kulseng i Eli Bastholm, kao i prevoditelj Davor Ričković. 
oštećenjem lubanje, koje je po sinu pokojnice prepoznato kao Marija Jurić. I na lokaciji 3. nađeno je žensko tijelo, koje je prema susjedu i nalazu osobne iskaznice prepoznato kao Marija Kostrić. Za ovaj je rad najvažniji nalaz s lokacije 4., zgarišta spaljene kuće, gdje su ispod ostataka stropa i žbuke nađene kosti više osoba. Očekivalo se da su to posmrtni ostaci vlasnika kuće Jure Kozića, žene mu Anke, njihove kćeri Vere Jurić i njezine djece, Darija i Tomislava Jurića. Uz kosti su nađeni dijelovi odjeće, krunica i čahure metaka. Pretraženo je i zgarište kuće Kate Bunjevac. Očekivao se pronalazak njezina tijela, ali ništa nije nađeno. ${ }^{187}$ Obdukcije na Zavodu za sudsku medicinu i kriminalistiku pokazale su da je u Kostrićima ekshumirano ukupno pet osoba. Kosti s lokacije 4., zgarišta kuće obitelji Kozić, pripadale su trima osobama, koje su dobile oznake ' $A$ ', 'B' i 'C' i koje su ubrzo identificirane:

- osoba 'A' kao Juro Kozić (1931.), umirovljenik iz Kostrića. Civil. ${ }^{188}$

- osoba 'B' kao Anka Kozić (1939.), domaćica iz Kostrića. Civil. ${ }^{189}$

- osoba 'C' kao Milka Jurić (1929.), domaćica iz Kostrića. Civil. ${ }^{190}$

Tako je potvrđen dio pretpostavke da nađene kosti pripadaju bračnom paru Kozić, no nisu nađeni posmrtni ostaci njihove kćeri i dvoje unučadi. Za dva tijela, nađena na drugim dvjema lokacijama, potvrđeno je da su to Marija Jurić (1930.), domaćica iz Kostrića, civil191, i Marija Kostrić (1924.), domaćica iz Kostrića, civil. ${ }^{192}$ No, prema međunarodnim standardima, ta se dva tijela ne vode kao nalazi iz masovne grobnice, već iz pojedinačnih grobova. Stoga se kao žrtve masovne grobnice Kostrići službeno vode tri osobe, Juro i Anka Kozić te Milka Jurić.

Budući da pri ekshumaciji nisu nađena tijela ostalih 11 stanovnika, ubijenih 1991., djelatnici PU sisačko-moslavačke nastavili su istragu. Prema podacima koje su dobili, na zgarištu kuće Kostrići kbr. 12. trebali su se nalaziti posmrtni ostaci Petra i Jelke Bašić. Stoga je 5. svibnja 1997. u Kostrićima, na toj lokaciji, Radna grupa iz sastava Komisije za zatočene i nestale Vlade Republike Hrvatske

$\overline{187}$ MB-UZN-STOZNDR. Zapisnik Istražnog odjela Županijskog suda u Sisku od 18. VII. 1996. u predmetu provođenja istražnih radnji ekshumacija posmrtnih ostataka civilnih i drugih žrtava rata na području općine H. Kostajnica u mjestu Kostrići i Cerovljani.

188 MB-UZN-STOZNDR. Personalni dosje Kozić Juro br. 622. i Zapisnik ZSMKZG o identifikaciji mrtvih tijela, od 1. X. 1996. Obdukciji br. Sp. 60.483-807/96.

189 MB-UZN-STOZNDR. Personalni dosje Kozić Anka br. 625. i Zapisnik ZSMKZG o identifikaciji mrtvih tijela, od 1. X. 1996. Obdukciji br. Sp. 60.484-808/96.

190 MB-UZN-STOZNDR. Zapisnik ZSMKZG o identifikaciji mrtvih tijela, od 6. XI. 1996. Obdukciji br. Sp. $60.485-809 / 96$

191 MB-UZN-STOZNDR. Personalni dosje Jurić Marija

192 MB-UZN-STOZNDR. Bilješka u elektronskoj evidenciji za Kostrić Petra Mariju (1924.), ekshumiranoj 18. srpnja 1996. u Kostrićima br. 13. 
ponovo izvršila ekshumaciju. ${ }^{193}$ Prema pronađenim posmrtnim ostacima na tom zgarištu, zaključeno je da su to vjerojatno dvije osobe. Pronađene, uglavnom spaljene i fragmentirane kosti, otpremljene su u Zavod za sudsku medicinu i kriminalistiku u Zagrebu. ${ }^{194}$ Analiza osteološkog materijala potvrdila je da su to ostaci dvoje odraslih osoba, žene i muškarca starosti preko 50 godina, koje su dobile identifikacijske brojeve NN 179 i NN 180. Uzrok smrti zbog stanja tijela nije se mogao odrediti. ${ }^{195}$ Uskoro je izvršena identifikacija tijela NN 179 kao Jelke Bašić (1942.), poljoprivrednice iz Kostrića, civila, i tijela NN 180 kao Petra Bašića (1940.), poljoprivrednika iz Kostrića, civila. ${ }^{196}$ Time se broj nađenih stanovnika Kostrića popeo na sedam. No, do danas nisu nađeni posmrtni ostaci još devetero mještana. ${ }^{197}$

Glede masovne grobnice, u nju nisu ubrojena ni dva tijela nađena 1997. Stoga se vodi kao masovna grobnica s trima žrtvama, kojima je zajedničko da su to starije civilne osobe, hrvatske nacionalnosti i rimokatoličke vjere. Dvije su žene, a jedan muškarac. Dvije su osobe bile u braku i imale djecu. U trenutku likvidacije sve su tri osobe bile nenaoružane. Stradali su u svojoj kući ili u neposrednom susjedstvu. Grobnica u Kostrićima u neposrednoj je vezi s masovnim grobnicama u Baćinu i na kostajničkom gradskom groblju te šumskom grobnicom u Cvetinu viru. Ukupno, one su rezultat etničkog čišćenja hrvatskog stanovništva preostalog u dubini teritorija pod srpskom okupacijom, a s ciljem dobivanja etnički homogenog teritorija.

$\overline{193}$ Komisiju su činili: predsjednik Županijskog suda u Sisku Josip Budinski i zapisničarka Ljerka Kolarić. Iz Radne grupe za lociranje, ekshumaciju i identifikaciju civilnih i vojnih žrtava rata ušli su: satnik Branko Bekavac - predstavnik MORH-a, natporučnik Marko Miloš - povjerenik Komisije za zatočene i nestale Vlade RH, dr. Stjepan Gusić sa ZSMKZG-a, dr. Drinko Baličević sa Zavoda za kliničku patologiju bolnice „Sestara milosrdnica“. Iz PUSM-a: Nikola Vidović, Elvir Šehić, Alojzije Đuračić, Ramiz Hodžić i Davor Cvetnić. Prisustvovali su promatrači EZ-a, Werner Zofal i Kramb Jochen, te prevoditelj Davor Ričković. Svi navedeni taj dan nisu radili u Kostrićima, već samo jedna skupina jer su se ostali nalazili na drugim lokacijama u Pounju.

194 MB-UZN-STOZNDR. Zapisnik Istražnog odjela Županijskog suda Sisak od 29. IV. 1997. KIR344/97., KIR-345/97. u predmetu provođenja istražnih radnji ekshumacija posmrtnih ostataka civilnih i vojnih žrtava rata na području općine H. Kostajnica.

195 MB-UZN-STOZNDR. Zapisnik ZSMKZG o obdukciji tijela NN 179 sa lok. 1. H. Kostajnica Kostrići k. br. 12. Sp. 61.921-862/97., od 6. V. 1997. i Zapisnik ZSMKZG o obdukciji tijela NN 180 sa lok. 1. H. Kostajnica Kostrići k. br. 12. Sp. 61.922-863/97., od 6. V. 1997.

196 MB-UZN-STOZNDR. Potvrda ZSMKZG o identifikaciji Jelke i Petra Bašić. Sp. 61.921862/97 i Sp. 61.922-863/97., od 19. VI. 1997.; PD Bašić Jelka br. 1727. i PD Bašić Petar br. 1726.

197 MB-UZN-STOZNDR. PD Bašić Petar br. 728.; PD Krizman Ferdinand br. 730.; PD Krizman Marija br. 731.; PD Kata Bunjevac. 


\section{Vasića Bare/Meminska}

Kronološki najmlađa masovna grobnica u hrvatskom Pounju nastala je u rujnu 1992., na lokaciji Vasića Bare, šumovitom proplanku nedaleko od kostajničkog sela Meminska. U njoj su nađena četiri tijela Bošnjaka. Oni su bili pripadnici skupine od 54 Bošnjaka iz Općine Prijedor, koji su u rujnu 1992. krenuli preko Kozare u izvlačenje u Republiku Hrvatsku, nakon što je Vojska Republike Srpske zauzela ovu općinu i provela progon nesrpskog stanovništva. U noći s 8. na 9. rujna 1992. kod Baćina ova skupina (koja se u srpskim dokumentima naziva „Zelene beretke“) prešla je Unu i krenula u smjeru Sunje, da bi je 10. rujna napali pripadnici Posebne jedinice milicije (PJM) Hrvatska Kostajnica. Dio je članova skupine uhvaćen i priveden u Hrvatsku Kostajnicu i Glinu, a mnogi su nakon zarobljavanja likvidirani. U izvješću PJM-a navodi se da je taj dan kod Cerovljana likvidirano dvoje, u šumi Zelenika 13, a na području Baćina 10 Bošnjaka te se i dalje radi na hvatanju ostataka navedene razbijene grupe. ${ }^{198}$

Među tada zarobljenima zasigurno su bila i ova četvorica Bošnjaka, koje je 29. rujna 1998. na lokaciji 2. Hrvatska Kostajnica - Vasića Bare ekshumirala Radna grupa za lociranje, ekshumaciju i identifikaciju civilnih i vojnih žrtava rata. ${ }^{199}$

Prema prikupljenim podacima, ondje su se trebala nalaziti četiri tijela, koja su nađena nakon ručnog iskapanja. Odmah je bilo vidljivo da se radi o zarobljenicima muškog spola, koji su likvidirani. Svoj četvorici na podlaktičnim kostima nađene su vezane omče od užadi, a jednoj su žrtvi konopom bile vezane i noge. Tri su žrtve bile u civilnoj odjeći s nešto stvari, a jedna je bila bez odjeće. Dani su im identifikacijski brojevi od NN 1324 do NN 1327. ${ }^{200}$ Tijela su prebačena u Zavod za sudsku medicinu i kriminalistiku u Zagrebu, gdje su kod jedne žrtve kao uzrok smrti utvrđene strijelne rane glave, dok se kod ostalih nije mogao utvrditi uzrok smrti. Kod jedne su žrtve utvrđeni višestruki lomovi ruke, koji su

\footnotetext{
198 HMDCDR. Fond Zonski Štab Teritorijalne odbrane Banija. Kut. 11. Vanredni operativni izveštaj Komande PJM Petrinja. Str. pov. br. 52-45., od 9. IX. 1992.; Izvještaj OB PJM Kostajnica o blokadi i hvatanju grupe u rejonu Cerovljani - Baćin, od 10. IX. 1992. i Kut. SM Dubica br. 2. Pregled punktova i kontrola za ilegalno prelaženje državne granice.

Iz Radne grupe za lociranje, ekshumaciju i identifikaciju civilnih i vojnih žrtava rata ušli su: satnik Branko Bekavac - predstavnik MORH-a (Odjel za ekshumacije), natporučnik Marko Miloš - povjerenik Komisije za zatočene i nestale Vlade RH, dr. Drinko Baličević sa Zavoda za kliničku patologiju bolnice „Sestara milosrdnica“ Zagreb. Iz PUSM-a: Nikola Vidović, Slaven Hadžikadunić, Boris Bobetko, Elvir Šehić, Miljenko Bošnjak i Goran Brebrić. Iz PP Dvor Stjepan Kušan; iz PP H. Kostajnica Dražen Grgurić; iz PP Novska Mladen Čorak; u prisutnosti promatrača misije EZ-a Gella Haralda i prevoditeljice Maje Buconjić

200 MB-UZN-STOZNDR. Zapisnik Istražnog odjela Županijskog suda Sisak od 28. IX. 1998. KIR-368/98., KIR-369/98., KIR-370/98., KIR-371/98. u predmetu provođenja istražnih radnji ekshumacije posmrtnih ostataka civilnih i vojnih žrtava rata na području općina H. Kostajnica, Dvor, Sunja i Petrinja.
} 

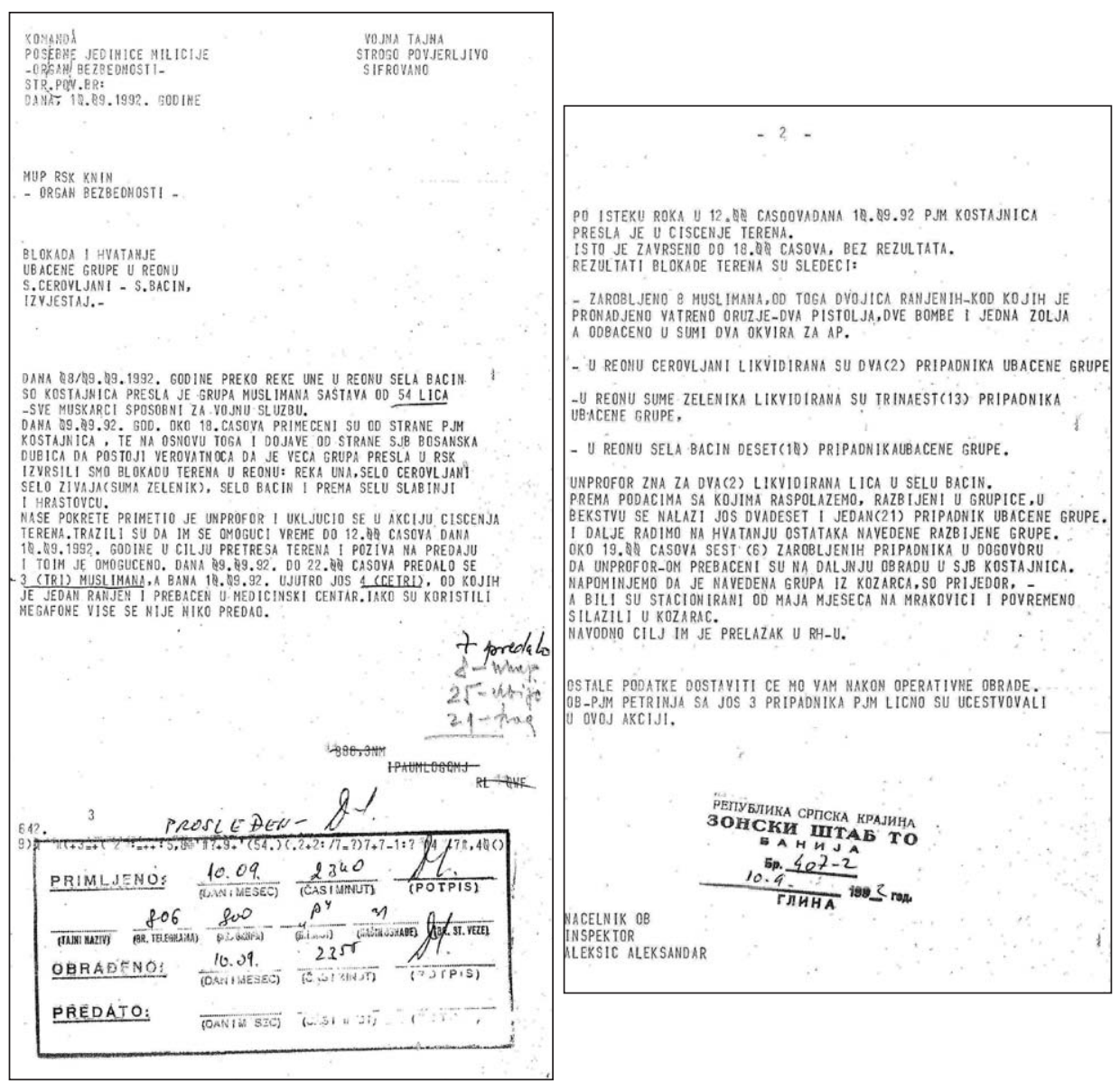

08 - Izvještaj Komande Posebne jedinice milicije RSK o likvidaciji veće skupine zarobljenih Bošnjaka u okolici Hrvatske Dubice u rujnu 1992. godine.

možda nastali od posljedica prethodnog zlostavljanja. ${ }^{201}$ Godinama se nije mogao otkriti identitet ubijenih osoba, da bi se konačno, u sklopu zajedničkog projekta s ICMP-om (International Commision on Missing Persons), preliminarnom identifikacijom DNK metodom utvrdilo da se radi o Bošnjacima iz prijedorskog sela Čarakovo, i to:

- tijelo NN 1324 identificirano je kao Izet Behlić (1966.).

- tijelo NN 1325 identificirano je kao Esad Kaltak (1947.).

$\overline{201}$ MB-UZN-STOZNDR. Protokol ZSMKZG o obdukciji tijela br. 1324. s lok. 2. Vasića Bare, od 20. XI. 1998.; Protokol ZSMKZG o obdukciji tijela br. 1325. lok. 2. Vasića Bare, od 21. X. 1998.; Protokol ZSMKZG o obdukciji tijela br. 1326. lok. 2. Vasića Bare, od 21. X. 1998.; Protokol ZSMKZG o obdukciji tijela br. 1327. lok. 2. Vasića Bare, od 21. X. 1998. 
- tijelo NN 1326 identificirano je kao Fikret Behlić (1963.).

- tijelo NN 1327 identificirano je kao Redžep Behlić (1956.). ${ }^{202}$

Budući da se radilo o građanima BiH, Uprava za zatočene i nestale Ministarstva obitelji, branitelja i međugeneracijske solidarnosti 2007. predala je posmrtne ostatke Institutu za nestale osobe $\mathrm{BiH}$, koji je proveo vlastiti identifikacijski postupak, kojim je potvrđen identitet spomenutih osoba. ${ }^{203}$

Prema sastavu žrtava, ova je grobnica najhomogenija. Četvorica muškaraca, od čega dvojica mlađe i dvojica srednje životne dobi, bošnjačke nacionalnosti $i$ islamske vjeroispovijesti, svi su zarobljeni za vrijeme borbenog djelovanja i likvidirani kao ratni zarobljenici. Iz dostupnih podataka nije jasan njihov status, no u srpskim dokumentima o borbi s tom skupinom Bošnjaka vidi se da su bili naoružani. ${ }^{204}$ Stoga se može smatrati da su te žrtve bile pripadnici Armije BiH.

\section{Pregled strukture žrtava iz masovnih grobnica u hrvatskom Pounju}

Da bi se dobio pun uvid u odlike žrtava, potrebno ih je analizirati prema statusnoj, etničkoj, spolnoj i dobnoj strukturi te s obzirom na njihovo zdravstveno stanje. To je moguće učiniti za 99 identificiranih žrtava, kao i za žrtve čije se zdravstveno stanje navodi u osobnim dosjeima. Potrebno je sagledati i vrijeme nastanka grobnica, što je moguće za sve žrtve. Preglednosti radi, ove se strukture donose tablično.

Struktura žrtava iz masovnih grobnica s obzirom na godinu pogubljenja/pogibije

\begin{tabular}{|c|c|c|}
\hline Godina & Broj & $\%$ \\
\hline 1991. & 107 & 93,8 \\
\hline 1992. & 5 & 4,4 \\
\hline 1993. & 1 & 0,9 \\
\hline Nepoznato & 1 & 0,9 \\
\hline Ukupno & 114 & 100 \\
\hline
\end{tabular}

$\overline{202}$ MB-UZN-STOZNDR. Dopis Instituta za nestale osobe BiH sa zahtjevom za predaju posmrtnih ostataka četiri državljana BiH ekshumiranih u mjestu Vasić Bare. Br. 01-40-152/2007., od 7. IX. 2007.

203 MB-UZN-STOZNDR. Bilješka o isporuci posmrtnih ostataka Ministarstva obitelji, branitelja i međugeneracijske solidarnosti. K1. 018-02/07-0002/6. Ur. br. 519-08-07-3., od 21. IX. 2007.; Obavijest Instituta za nestale osobe BiH o identifikaciji Behlić (Esad) Fikreta VB-1326. Br. 01-40-316/2007., od 3. XII. 2007.

204 HMDCDR. Kut. SUP Glina - Uvez PJM Petrinja. Izvještaj Komande PJM Petrinja. Str. pov. br. 52-47., od 11. IX. 1992. 
Struktura identificiranih žrtava ekshumiranih iz masovnih grobnica s obzirom na status

\begin{tabular}{|c|c|c|}
\hline Status & Broj & $\%$ \\
\hline Pripadnici oružanih formacija & 23 & 23,3 \\
\hline Civili & 76 & 76,7 \\
\hline Ukupno & 99 & 100 \\
\hline
\end{tabular}

Struktura identificiranih žrtava iz masovnih grobnica s obzirom na etničku pripadnost

\begin{tabular}{|c|c|c|}
\hline Spol & Broj & $\%$ \\
\hline Hrvati & 92 & 93 \\
\hline Bošnjaci & 4 & 4 \\
\hline Srbi & 3 & 3 \\
\hline Ukupno & 99 & 100 \\
\hline
\end{tabular}

Struktura identificiranih žrtava ekshumiranih iz masovnih grobnica s obzirom na spol

\begin{tabular}{|c|c|c|}
\hline Spol & Broj & $\%$ \\
\hline$M$ & 62 & 63 \\
\hline$\check{Z}$ & 37 & 37 \\
\hline Ukupno & 99 & 100 \\
\hline
\end{tabular}

Struktura identificiranih žrtava ekshumiranih iz masovnih grobnica s obzirom na dob

\begin{tabular}{|c|c|c|}
\hline Dob & Broj osoba & $\%$ \\
\hline $19-30$ & 21 & 21,2 \\
\hline $31-45$ & 11 & 11,1 \\
\hline $46-60$ & 27 & 27,2 \\
\hline$>60$ & 40 & 40,4 \\
\hline Ukupno & 99 & 100 \\
\hline
\end{tabular}

Struktura identificiranih žrtava iz masovnih grobnica s obzirom na teže zdravstveno stanje u ukupnom broju od 99 identificiranih žrtava

\begin{tabular}{|c|c|c|}
\hline Zdravstveno/fizičko stanje & Broj & $\%$ \\
\hline Ranjenici & 4 & 4 \\
\hline Teški bolesnici & 19 & 19 \\
\hline Invalidne osobe & 6 & 6 \\
\hline Ukupno od 99 ident. žrtava & 29 & 29 \\
\hline
\end{tabular}




\section{Zaključna razmatranja}

Osim što sama brojnost masovnih grobnica u hrvatskom Pounju, kao i broj žrtava u njima, govori o silini i karakteru agresije na Republiku Hrvatsku, prirodu agresora i njegove namjere sustavnog etničkog čišćenja nesrpskog stanovništva dobro ilustrira i razdioba žrtava s obzirom na dob, spol, status i etničku pripadnost. Većinu od 99 identificiranih osoba iz masovnih grobnica čine kategorije stanovništva koje su posebno zaštićene međunarodnim humanitarnim pravom, odnosno civili, starije osobe i žene. Tako civili čine $76,7 \%$ od ukupnog broja žrtava; čak su $37 \%$ žene, osoba je starijih od 60 godina $40,4 \%$, a $29 \%$ osoba su ranjenici, teški bolesnici i invalidne osobe. Od 99 identificiranih osoba samo su dvije stradale boreći se u oružanom sukobu, dok ih je 97 planski likvidirano nakon otmice i/ili nasilnog odvođenja. I za 14 neidentificiranih osoba postoje jasne naznake da su likvidirane nakon zarobljavanja/otmice. Dokaz je etničkog čišćenja i nacionalni sastav identificiranih. Od ukupnog su broja identificiranih osoba 93\% Hrvati, 4\% Bošnjaci te 3\% Srbi, koji su ostali lojalni Republici Hrvatskoj ili su pokušali zaštiti svoje susjede Hrvate, zbog čega su i ubijeni. Upravo ovi nalazi - velik obim likvidacija nakon zarobljavanja/otmice te predominantni civilni i neborački tip žrtava, kao i gotovo potpuna etnička homogenost žrtava - pokazuju karakter i težinu ratnih zločina te potvrđuju da su žrtve iz masovnih grobnica dio planiranog i organiziranog zločina s ciljem etničkog čišćenja okupiranog područja, a ne posljedica borbenih djelovanja tijekom rata. Činjenica da su prve masovne grobnice u Hrvatskoj nastale u hrvatskom Pounju, i to već krajem srpnja 1991., ukazuje da je zbog strateškog položaja - spojnice između dviju „,srpskih“ zemalja - SAO Krajine i Bosanske krajine - hrvatsko Pounje postalo prvo poprište provedbe projekta etničkog čišćenja dijelova Hrvatske, koji su trebali ući u sastav Velike Srbije, čime bi se dobila etnička homogenost, te da su masovne grobnice samo jedna od metoda u provedbi ovoga projekta.

\section{Bibliografija}

\section{Neobjavljeni izvori}

Arhiv Policijske uprave Sisačko-moslavačke

Arhiv Policijske uprave Zagreb

Arhiv Županijskog državnog odvjetništva Sisak

Hrvatski memorijalno-dokumentacijski centar Domovinskog rata. Fond Zonski Štab Teritorijalne odbrane Banija.

Ministarstvo branitelja - Uprava za zatočene i nestale - Sektor za traženje osoba zatočenih i nestalih u Domovinskom ratu. 


\section{Objavljeni izvori}

Narodne novine, Zagreb

PANDŽA ORKAN, Ivica (ur.). 2012. Vojska Krajine u Pounju i na Banovini (zapisi komšija). Sisak: Agencija za istraživanje i dokumentaciju ratnih sukoba.

Vojna operacija ,Oluja“ i poslije: izvještaj. 2001. Zagreb: Hrvatski Helsinški odbor za ljudska prava.

Popis stanovništva 1991. - narodnosni sastav stanovništva Hrvatske po naseljima. 1992. Zagreb: Republički zavod za statistiku Republike Hrvatske.

\section{Literatura}

GRUJIĆ, Ivan. 2000. Zatočeni, nestali, nasilno odvedeni - masovne grobnice žrtava agresije. U Hrvatski žrtvoslov-zbornik radova Prvog hrvatskog žrtvoslovnog kongresa Zagreb, 19./21. VI. 1998. Knj. 2., ur. Zvonimir Šeparović, 29-37. Zagreb: Hrvatsko žrtvoslovno društvo.

GRUJIĆ, Ivan, Višnja BILIĆ. 2009. Zatočeni, nestali i masovne grobnice: žrtve i dokazi zločina. U Demografski kontekst i sociokulturne posljedice Hrvatskoga domovinskog rata, ur. Dražen Živić i Ivana Žabec, 29-43. Zagreb-Vukovar: Institut društvenih znanosti „Ivo Pilar“, Područni centar Vukovar.

NAZOR, Ante. 2007. Počeci suvremene hrvatske države (kronologija procesa osamostaljenja Republike Hrvatske: od Memoranduma SANU 1986. do proglašenja neovisnosti 8. listopada 1991.). Zagreb: Hrvatski memorijalno-dokumentacijski centar Domovinskog rata.

PLESKALT, Željko. 2002. Zaostali u vječnosti ljubeći oltar Domovine: Kusonje 1991., 1993., Bjelovar: Državni arhiv u Bjelovaru.

\section{Mass Graves in Croatian Region of Pounje from Croatian Homeland War - A Contribution to Victimological Studies}

Coatian region of Pounje, area of Republic Croatia bordering with the Republic Bosnia and Herzegovina, today a part of Sisak-Moslavina county, was under the Serbian occupation during the Croatian Homeland War. Due to important geostrategic position of this region, Serbian militia and army started here their first big ethnic cleansing of the local Croatian population, which made up 19\% of whole population.

As a result of that, in July 1991, it was in Croatian Pounje that the first mass graves appeared in Republic Croatia. Up to 2015, 11 mass graves have been discovered in this region, originating from the period between 1991 and 1993. 114 victims have been exhumed from them, with 99 bodies identified. As for ethnic category, majority of the identified victims were Croats $-93 \%$, Bosnians $-4 \%$, and $3 \%$ of Serbs who worked for Croatian police or who tried to protect their 
Croatian neighbours, because of which they were killed. Furthermore, majority of victims were persons with special protection according to international humanitarian right, such as civilians $76,7 \%$, the elderly $40,4 \%$, women $37 \%$, the wounded, seriously sick and invalids $29 \%$.

Regarding circumstances of death, just 2 victims from mass graves were killed in a battle, whilst 97 were intentionally executed after the Serbian army conquered this region. All known executioners were members of Serbian militia or army.

Large number of mass graves, a lot of bodies found in them, planned executions and structure of victims regarding civilian status, gender and age, as well as almost complete ethnic homogeneity imply that mass graves in Croatian region of Pounje are not a consequence of military war activities. They are a direct result of committing a planned and organized crime of ethnic cleansing of parts of Croatia which were about to become parts of the future big Serbian national state.

Mass destruction of Croatian population was carried out with the intention to get ethnically homogeneous region to be easily joined with Serbian state, and mass graves as the result of executions of Croatian population, were just one of the methods of realisation of the project of Big Serbian National State.

Keywords: Croatian Homeland War, Croatian Pounje, Sisak-Moslavina county, ethnic cleansing, war crimes, mass graves, SAO Krajina

Ključne riječi: Domovinski rat, hrvatsko Pounje, Hrvatska Kostajnica, etničko čišćenje, ratni zločini, masovne grobnice, SAO Krajina

Jakša Raguž

Hrvatski institut za povijest

HR-10000 Zagreb, Opatička 10

jraguz@isp.hr 


\section{FILOZOFSKI FAKULTET SVEUČILIŠTA U ZAGREBU \\ ZAVOD ZA HRVATSKU POVIJEST \\ INSTITUTE OF CROATIAN HISTORY \\ INSTITUT FÜR KROATISCHE GESCHICHTE}
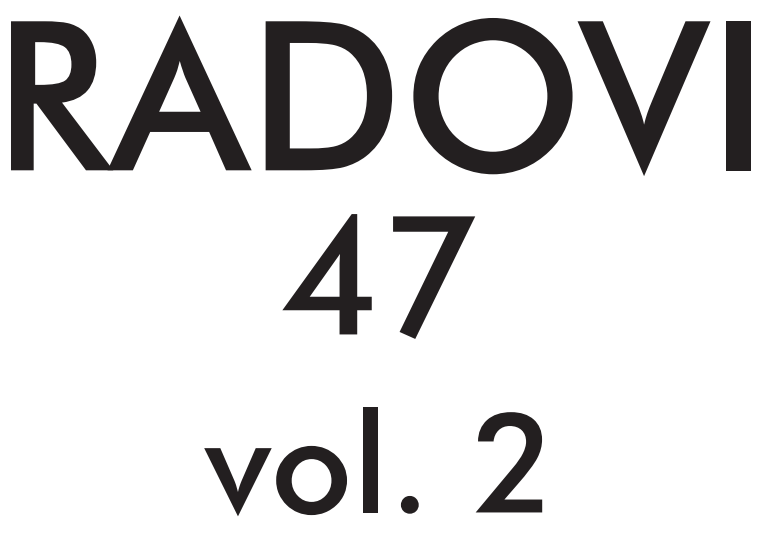

ZAVOD ZA HRVATSKU POVIJEST

FILOZOFSKOGA FAKULTETA SVEUČILIŠTA U ZAGREBU

FF press

ZAGREB 2015. 


\title{
RADOVI ZAVODA ZA HRVATSKU POVIJEST FILOZOFSKOGA FAKULTETA SVEUČILIŠTA U ZAGREBU
}

\author{
Knjiga 47, vol. 2
}

\author{
Izdavač / Publisher \\ Zavod za hrvatsku povijest \\ Filozofskoga fakulteta Sveučilišta u Zagrebu \\ FF-press \\ Za izdavača / For Publisher \\ Vlatko Previšić \\ Glavni urednik / Editor-in-Chief \\ Hrvoje Gračanin \\ Izvršna urednica / Executive Editor \\ Inga Vilogorac Brčić \\ Uredništvo / Editorial Board
}

Bruna Kuntić-Makvić (stara povijest/ancient history), Zrinka Nikolić Jakus (srednji vijek/ medieval history), Hrvoje Petrić (rani novi vijek/early modern history), Željko Holjevac (moderna povijest/modern history), Tvrtko Jakovina (suvremena povijest/contemporary history),

Silvija Pisk (mikrohistorija i zavičajna povijest/microhistory and local history),

Zrinka Blažević (teorija i metodologija povijesti/theory and methodology of history)

Međunarodno uredničko vijeće / International Editorial Council

Denis Alimov (Sankt Peterburg), Živko Andrijašević (Nikšić), Csaba Békés (Budapest), Rajko Bratož (Ljubljana), Snježana Buzov (Columbus, Ohio), Svetlozar Eldarov (Sofija), Toni Filiposki (Skopje), Aleksandar Fotić (Beograd), Vladan Gavrilović (Novi Sad), Alojz Ivanišević (Wien),

Egidio Ivetić (Padova), Husnija Kamberović (Sarajevo), Karl Kaser (Graz),

Irina Ognyanova (Sofija), Géza Pálffy (Budapest), Ioan-Aurel Pop (Cluj),

Nade Proeva (Skopje), Alexios Savvides (Kalamata), Vlada Stanković (Beograd), Ludwig Steindorff (Kiel), Peter Štih (Ljubljana)

Izvršna urednica za tuzemnu i inozemnu razmjenu / Executive Editor for Publications Exchange Kristina Milković

Tajnik uredništva / Editorial Board Assistant
Dejan Zadro

Adresa uredništva/Editorial Board address

Zavod za hrvatsku povijest, Filozofski fakultet Zagreb, Ivana Lučića 3, HR-10 000, Zagreb

Tel. ++385 (0)1 6120 150, 6120 158, faks ++385 (0)1 6156879

Časopis izlazi jedanput godišnje / The Journal is published once a year

Časopis je u digitalnom obliku dostupan na / The Journal in digital form is accessible at Portal znanstvenih časopisa Republike Hrvatske „Hrčak“ http://hrcak.srce.hr/radovi-zhp

Financijska potpora za tisak časopisa / The Journal is published with the support by

Ministarstvo znanosti, obrazovanja i športa Republike Hrvatske

Časopis je indeksiran u sljedećim bazama / The Journal is indexed in the following databases:

Directory of Open Access Journals, EBSCO, SCOPUS, ERIH PLUS 
Naslovna stranica

Iva Mandić

Grafičko oblikovanje i računalni slog

Marko Maraković

Lektura

Samanta Paronić

Tisak

Web2tisak, Zagreb

Naklada

250 primjeraka

Časopis je u digitalnom obliku dostupan na Portalu znanstvenih časopisa Republike Hrvatske ,Hrčak“ http://hrcak.srce.hr/radovi-zhp

The Journal is accessible in digital form at the Hrcak - Portal of scientific journals of Croatia http://hrcak.srce.hr/radovi-zhp 


\section{RADOVI 47}

\section{vol. 2}

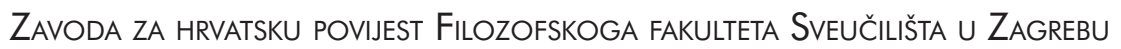

